\title{
STOCK DIVIDENDS AND SECTION 305: REALIZATION AND THE CONSTITUTION $\dagger$
}

\author{
GARY E. BASHIAN*
}

The Latin phrase ipse dixit, it speaks for itself, would be a misleading maxim as an interpretation of the tax treatment of stock dividends. The tax treatment of stock dividends or rights has been under the watchful scrutiny of the Treasury Department since the inception of the Federal income tax with the enactment of the Revenue Act of 1913.1 The recent revision of section 305 by the Tax Reform Act of $1969^{2}$ has brought about comprehensive changes having significant ramifications in other areas of tax law. The present status of stock dividends is very much a composite of its history, especially since the recent revisions have returned to the proportionate interest, or ownership, test of the pre-1954 Code.

\section{HISTORY}

A stock dividend is a dividend in the form of shares of any class of the distributing company's own stock $^{3}$ normally preceded by a transfer from a surplus account, usually earned surplus, to the capital

$\dagger$ Copyright $\odot$ Gary E. Bashian.

* A.B. 1964, Gettysburg College; J.D. 1967, Boston University School of Law; LL.M. (in Taxation) 1971, New York University School of Law; associated with Clark, Gagliardi, \& Miller, White Plains, New York.

The author wishes to express his appreciation to Professor Gerald L. Wallace and Professor Victor Zonana of the Graduate Tax Department of New York University Schoool of Law.

1. 38 Stat. 114 (1913).

THE FOLLOWING HEREINAFTER CITATIONS WILL BE USED IN THIS ARTICLE:

Hearings on H.R. 13270 Before the Senate Fin. Comm., 9lst Cong., 1st Sess. (1969) [hereinafter cited as 1969 Senate Hearings];

Hearings on H.R. 13270 Before the House Ways and Means Comm., 91st Cong., lst Sess. (1969) [hereinafter cited as 1969 House Hearings];

S. REP. No. 552, 9 lst Cong., lst Sess. (1969) thereinafter cited as S. REP. No. 5521;

H.R. ReP. No. 413, 9Ist Cong., Ist Sess. (1969) [hereinafter cited as H.R. ReP. No. 413];

B. Bittker \& J. Eustice, Federal Income Taxation of Corporations and ShareholdERS (3d ed. 1971) [hereinafter cited as BITTKER \& EUSTICE].

2. 83 Stat. 614 (1969).

3. Common stock is the class of stock representing the residual ownership of the assets of a corporation, after the liabilities and other proprietory claims have been satisfied, with certain fundamental legal rights. Preferred stock is the class of stock which has a claim prior to common stockholders upon the earnings of a corporation, and also usually on the assets upon liquidation. E. KoHLer, Dictionary FOR ACCOUNTANTS $102 \& 372$ (2d ed. 1961). 
account, thereby increasing the capital stock and, in effect, capitalizing past earnings. ${ }^{4} \mathrm{~A}$ taxpayer would like to have any increase in net worth, or gain, classified as non-realized, or if realized, at least subject to the favored status of capital gain..$^{5}$ Over the years, Congress has enacted a multitude of provisions enabling the Treasury to reach and prevent the escape of income through stock dividends. ${ }^{6}$ However, there is the important qualification that some form of realization is a necessary requirement to the taxation of accretion to capital. ${ }^{7}$

The first case concerning the taxation of stock dividends after the enactment of the Revenue Act of 1913 was Towne $v$. Eisner, ${ }^{8}$ where the Supreme Court ruled that a stock dividend of common on common was not net income under the Act, which provided that income

4. This should be contrasted to a "split-up" where there is a mere dividing up of the outstanding shares into more share units, thereby only reducing the per share value-either the par or stated value - of each outstanding share and increasing the total number of shares issued. No extra value is received by the shareholders and there is no change in the legal or stated capital to the corporation.

5. Burnet v. Logan, 283 U.S. 404 (193I). The Tax Reform Act has somewhat equalized the rate structure of capital gains versus ordinary income by raising the capital gains rates. See also INT. REv. CODE OF 1954, § 1348 (50\% maximum rate on earned income).

6. See INT. REv. Code OF I954, §§ 302, 305, 306, 341, 368 (269 \& 1551, I561-64, 354-56, 38I), 385, 482, 53I, 541, 545; Gregory v. Helvering, 293 U.S. 465 (1935). See also James v. United States, 366 U.S. 313 (I961); Old Colony Trust Co. v. Comm'r, 279 U.S. 716 (1929); Eisner v. Macomber, 252 U.S. 189 (I920). S. Surrey \& W. Warren, Federal Income TaxaTION: CASES AND MATERIALS 101-216 (1960) (especially 207-16 as to the varying approaches to defining income).

7. The source of the power granted to Congress to tax is derived from the sixteenth amendment which states: "The Congress shall have power to lay and collect taxes on incomes, from whatever source derived, without apportionment among the several States, and without rcgard to any census or enumeration." This amendment removed the apportionment requirement of U.S. Consr. art, I, $\$ 2 \& 9$, which applied to any direct tax. Pollack v. Farmers' Loan and Trust Co., 158 U.S. 60I (1895), had held that taxes upon rents and profits of real estate and upon returns from investments of personal property were in effect direct taxes upon the property from which such income arose, and apportionment was required.

8. 245 U.S. 4I8, 426 (1918). For historical analysis of stock dividends see generally Comment, An Analysis of the Taxation of Stock Dividends from 1918 to 1970; Effects of the Tax Reform Act of 1969 on $\S 305$ of the Internal Revenue Code, 8 DUQUESNE L. REv. 364 (1970); Comment, The Taxation of Stock Dividends and the Tax Reforn Act of 1969_Foreboding Implications and Constitutional Uncertainties, 24 VAND. L. REV. 545 (1971).

9. 38 Stat. 114 (1913). The Court cited Gibbons v. Mahon, 136 U. S. 549, 559-60 (1890), which had said:

A stock dividend really takes nothing from the property of the corporation, and adds nothing to the interests of the shareholders. Its property is not diminished, and their interests are not increased. . . . [T/he proportional interest of each shareholder remains the same. The only change is in the evidence which represents that interest, the new shares and the original shares together representing the same proportional interest that the original shares represented before the issue of the new ones. 
included "dividends" and "gains or profits and income derived from any source whatever." 9 The Revenue Act of $1916^{10}$ explicitly sought to tax all stock dividends, but the landmark decision of Eisner v. Macomber ${ }^{11}$ struck down that provision by holding that a stock dividend of common on common - with only the one class of common outstanding - was not within the definition of income as stated in the sixteenth amendment. The Court said that not only does a stock dividend really take nothing from the property of the corporation and add nothing to that of the shareholder, but that the antecedent accumulation of profits evidenced thereby, while indicating that the shareholder is the richer because of an increase of his capital, at the same time shows he has not realized or received any income in the transaction. ${ }^{12}$

In response to Eisner $v$. Macomber, the Revenue Act of $1921^{13}$ provided that a "stock dividend shall not be subject to tax." This effectively precluded taxation of any stock dividend regardless of whether the shares distributed were common or preferred, and without consideration of the number of classes of stock already outstanding; the facts of Macomber, however, had been limited to a dividend of common on common, with no other classes outstanding. Regulations issued after passage of the Revenue Act of 1921 simply stated that no income would result to the shareholder receiving a stock dividend and the original stock's basis should be allocated to all the stock owned. Nothing of grave import affected this area of the tax law until fifteen years later when, in the midst of congressional revision of what was to become the Revenue Act of $1936,{ }^{14}$ the Supreme Court held in

10. 39 Stat. 756 (1916).

11. 252 U.S. 189 (1920). The decision was 5-4. Mr. Justice Holmes, with Mr. Justice Day concurring, dissented and succinctly stated that the "incomes" of the sixteenth amendment should be read within its known purpose as a means of permitting a tax on incomes (a direct tax) to be levied with the apportionment requirement and within the common understanding at the time it was adopted. Id. at 212-13.

Mr. Justice Brandeis, with whom Mr. Justice Clark joined, dissented in a more lengthy and descriptive manner with special emphasis on the resulting evasion.

For a discussion of Eisner see Lowndes, The Taxation of Stock Dividends and Stock Rights, 96 U. PA. L. Rev. 147 (1947); Powell, Stock Dividends, Direct Taxes, and the Sixteenth Amendment, 20 Colum. L. Rev. 536 (1920); Rottschaefer, Present Taxable Status of Stock Dividends in Federal Law. 28 Mins. L. Rev. 106, 163 (1944); Seligman, Implications and Effects of the Stock Dividend Decision, 2 I Colum. L. Rev. 313 (1921).

12. 252 U.S. at 212.

13. 42 Stat. 227 (1921).

14. 49 Stat. 1648 (1936). 
Koshland $v$. Helvering ${ }^{15}$ that Congress did have the power to tax certain stock dividends. ${ }^{16}$ In Koshland, the taxpayer had owned cumulative nonvoting preferred and had received a dividend of common voting stock - the only other class of shareholders was common which had received nothing. The taxpayer, claiming no allocation was necessary, argued the full cost basis should be used when the preferred stock was sold. The Court, agreeing there was no statutory authority for the allocation since this stock dividend could have been taxed as "income" had Congress desired, said that "[W]here a stock dividend gives the stockholders an interest different from that which his former stock holdings represented he receives [taxable] income." "17 The Court also noted that a number of cases involving exchanges in reorganizations had distinguished between a stock dividend which worked no change in the corporate entity and exchanges which did result in changes in the corporate identity, or distributions giving a shareholder a proportional interest different from what he formerly held. ${ }^{18}$

The Koshland case and the Revenue Act of 1936, coming during mid-depression years, have an important relationship to the present tax status of stock dividends, since in effect the proportionate interest

15. 298 U.S. 441 (1936).

16. Legislation concerning stock dividends has continued to be peculiarly sensitive to Supreme Court decisions. In fact, the reflex-like reaction between the statutes and decisions can be viewed with the aid of hindsight, and some foresight, as a continuing endeavor by the Treasury to rightfully include all stock dividends within the definition of income. The new section 305 of the Tax Reform Act has shifted the balance, consequently the Treasury is again on the offensive, and with its specific limitations and broad general regulatory power could whittle Macombcr down to a size easily disposable by further Congressional action.

I7. 298 U.S. at 446.

18. Id. at 445 \& n.8. The following reorganization cases were cited: Marr v. United Statcs, 268 U.S. 536 (1925) (a reincorporation in a different state held to be a taxable exchange of securities because the gain was represented by securities of a different character in a different corporation); Cullinan v. Walker, 262 U.S. 134 (1923) (the assets in liquidation were transferred to two corporations and then to a holding company, the distribution of holding company stock and the two corporation's bonds held to be income because it was a realization of appreciated gain); Rockefeller v. United States, 257 U.S. 176 (1921) (the old corporation's distribution of the stock of its newly created corporation resulted in income because of a severance and partial realization of gain); United States v. Phellis, 257 U.S. 156 (1921) (a reorganization whereby the old company remained as a shell and the new company's stock was distributed resulted in income since the new common represented accumulated earnings and profits and the new property was a severance from the capital). But compare Marr with Weiss v. Stearn, 265 U.S. 242 (1924) (an ( $F$ ) reorganization, mere change in identity, was the result and thus no tax under the Macomber rationale).

As to the precise meaning of "the same interest" of "shares" and "change in the nature of shares" see notes 15-17 supra and accompanying text. 
test of the present section 305 is an updated version of the older law. Also, in 1936, the medium of payment election exception, which has since remained continuously in one form or another, was promulgated for the first time. The Revenue Act of 1936, approved on June 22, 1936 , used the broadest terminology to tax the receipt of all stock dividends that were, in fact, "income" under the sixteenth amendment. ${ }^{19}$ Contrary to the position asserted by several commentators, ${ }^{20}$ the Revenue Act of 1936 was not written or enacted in response to Koshland, and the interaction between those events was surprisingly negligible. The case was decided on May 18, 1936, ${ }^{21}$ and the decision came as a surprise to Congress which had been preparing and drafting the Revenue $\mathrm{Act}^{22}$ in the midst of what history has shown was probably the lowest point of our economic well being. ${ }^{23}$ The Finance Com-

19. "A distribution made by a corporation to its shareholders in its stock or rights to acquire its stock shall not be treated as a dividend to the extent that it does not constitute income to the shareholder within the meaning of the Sixteenth Amendment to the Constition." 1nt. Rev. Act of 1936, ch. 690, § 115(f)(1), 49 Stat. 1648, 1688.

20. See, e.g., Lowndes, supra note 11, at 148; An Analysis of the Taxation of Stock Dividends, supra note 8, at 366-67; The Taxation of Stock Dividends, supra note 8, at 548-49.

21. The petition for certiorari was granted on March 30, 1936.

22. On March 20, 1936 the House Ways and Means Committee had begun hearings on the Revenue Act of 1936 and these continued until April 7. The Bill was introduced to the House on April 21, 1936 and to the Senate on April 24. The Senate Finance Committee Hearings ran from April 30-May 12 (confidential Senate hearings from April 23-May 29).

The Senate Hearings, as had been the case in the House Hcarings, devotcd almost the entire volume to the Presidential Proposals revising the corporate tax structure. See Hearings on H.R. 12395 Before the Senate Fin. Comm., 74th Cong., 2d Sess. (1936).

23. It is significant to note that the Revenue Act of 1936 was enacted while the United States was in the throes of the Great Depression and this was the last year of President Roosevelt's first term in office, whereas the Tax Reform Act of 1969 was more concerned with rectifying abuses and being more equitable than as a source of new and larger revenues. Prcsident Nixon's proposals for the 1969 Tax Reform Act stated:

We must reform our tax structure to make it more equitable and efficient; we must redirect our tax policy to make it more conducive to stable economic growth and responsive to urgent social needs....

Tax dollars the Government deliberately waives should be viewed as a form of expenditure, and weighed against the priority of other expenditures . . . .

We shall nevcr make taxation popular, but we can make taxation fair. 1969 House Hearings pt. 14 at 5049.

The 1969 proposals aimed at the abuses pertaining to preferences, private foundations, and the allocation of deductions. The prepared Treasury statement by Assistant Secretary Cohen before the Senate Finance Committee on September 4, 1969, indicated that a tax relief would result to individuals in a net long term shift in the burden between individuals and corporations. In fact, the total effect would be a long-term revenue loss per year from \$1.3 billion to $\$ 2.4$ billion. 1969 Senate Hearings pt. 1, at 549. The Treasury proposals before the House Ways and Means Committee, at 5058, in Table 1 even estimated neither increase nor decrease in revcnues 
mittee reported the proposed act to the Senate on June 1, 1936 after Koshland, but the wording of the stock dividend section was for all practical purposes the same as when originally presented prior to Koshland. ${ }^{24}$ In fact, the broad general phraseology was used in the statute because it was not known to what extent, if any, stock dividends could be taxed. Mr. Kent, Acting Chief Counsel of the Bureau of Internal Revenue stated in the House Hearings prior to the Court's decision that the general immunity of Macomber might not be applic-

from stock dividends although this was qualified at 5055 . "This provision will prevent a substantial future loss of revenue." 1969 House Hearings pt. 14, at 5058, 5055. Secretary Cohen's prepared statement before the Senate Finance Committee on September 4, 1969 reaffirmed the revenue generating need of the stock dividend provision. "Without such a provision substantial revenue losses resulting from circumvention of existing law are anticipated." 1969 Senate Hearings 591.

Contrast this to 1936, when President Roosevelt'was pressing his attack against the depression by spending and pump priming the economy. His opponents favored a balanced budget with expenditures limited to the smaller revenues. In 1969, the budget and income revenues werc over $\$ 200$ billion with Viet Nam, inflation, and the environment the most pressing problems. In 1939, President Roosevelt needed money to spend and would use any form of income taxation to obtain it, even suggesting a tax on undistributed income of a corporation directly upon the shareholders. H.R. Doc. No. 418, 74th Cong., 2d Sess. 2-3 (1936).

President Roosevelt believed the accumulation of surplus tax should be revamped to stop the "leak" of an estimated $\$ 4.5$ billion of corporate income and a new undistributed corporate income tax (on corporations) should be added. The yield from all the taxing measures would be $\$ I .7$ billion and would arise "primarily from those who are now able to avoid their just share . . . by holding income-producing property in the corporatc form, and by having their corporations retain very large proportions of these earnings." Hearings on H.R. 12395 Before the Senate Finance Comm., 74th Cong., 2d Sess. 24 (1936). The figures have grcater meaning when placed in the context of other 1936 cconomic figures such as income tax collections of \$1.4 billion, total internal revenue collections of $\$ 3.5$ billion, total government receipts of $\$ 4.1$ billion with expenditures of $\$ 8.8$ billion, and a growing public debt of $\$ 33.7$ billion. WorLd ALMANAC 295-97 (1937). See generally R. Moley, The First New Deal (1966).

24. On June I, the Senate Finance Committee reported out subsection $115(1)(1)$, in the form in which it is found in the Revenue Act of 1936. S. REP. No. 2156, 74th Cong., 2d Sess. 18-19 (1936). There had been no alterations made to reflect the Koshland case decided two weeks earlier on May 18. Senators Black and LaFollette of the Senate Finance Committee submitted a minority report which included recommendations that subsection $115(1)(1)$ specifically adopt the formula of the Koshland case. The belief was that in its existing form the section did not clearly tax even the type of stock dividends which the Court held properly taxable in Koshland. See S. Rep. No. 2156, 74th Cong., 2d Sess., pt. 2, at 5-6 (1936) and 80 ConG. Rec. 8527-8528 (1936). During the debate on the Senate floor (June 5, 1936), Senator Robinson stated his approval of the minority report amendments to the Act, but suggested the amendments be withdrawn and the matter taken up in conference. This was done and quickly condemned by Senator Norris as illogical, since the conference would probably not even consider a point neither included in the bill nor noted as revealing the temper of the Senate. 80 CoNG. REC. 9052, 9054 (1936). The amendments were withdrawn and as predicted not mentioned or acted upon by the conference committee. 
able to all types of stock dividends, and asserted that some forms of stock dividends were taxable. He cited as examples of taxable stock dividends the payment of a common stock dividend, in lieu of a large cash distribution, to preferred shareholders, and the optional stock dividend of cash or stock. ${ }^{25}$

The final language of the Act was essentially that approved by the House prior to Koshland. On April 27, 1936 Congressman Vinson, before the full House, placed in the record 28 cases involving the taxation as income of stock dividends, 16 of which had held the stock dividends or rights received were a mere change of form and not the realization of income while the remaining 12 had held that the dividends were not true stock dividends and thereby should be treated as realized taxable income. Typically, the latter cases, which did not include the reorganization cases, ${ }^{26}$ were of the election variety now covered by subsection $305(\mathrm{~b})(1) .{ }^{27}$ Congressman Vinson asserted that the language of the 1921 statute was too broad and went beyond Macomber. ${ }^{28}$ The House, hard pressed for revenues, approved language authorizing the Treasury to tax whatever stock dividends might be deemed "income." A more passive section could not have been enacted. ${ }^{29}$

25. Congressman Vinson stated in conclusion that "such option is property that has a value and, in your opinion, takes that entirely out of the stock dividend which was involved in the case of Eisner v. Macomber; is that right?"

Mr. Kent: "That is correct." Hearings on H.R. I2395 Before the House Ways and Means Comm., 74th Cong., 2d Sess., at 593 (1936).

26. See cases cited in note 18 supra.

27. See 80 Cong. Rec. 6215 (1936), citing Wood v. Comm'r, 29 B.T.A. 735 (1934) (6\% preferred given option of cash dividend or new 7\% preferred), and Paper v. Comm'r, 29 B.T.A. 523 (1933) (resolution gave option to take dividends in cash or preferred stock).

28. Mr. Vinson: "Well, we take the broad position that stock dividends that are taxable income within the sixteenth amendment are subject to taxation, and if they are not such stock dividends and not any taxable ineome under the sixteenth amendment, they are not subject to taxes."

Mr. Treadway: "The only comment 1 may add to the very excellent explanation which the gentleman has given is that, so far as I know, this subject matter was not taken up either by the committee or the subcommittee until this bill appeared in print and we voted it in bloc form. Am I right?"

Mr. Vinson: "That is correct so far as the full committee is concerned, but I may say that the Democratic majority gave considerable thought to this language and to the purpose. So far as I know, there is no one who is objecting or could object to the policy that we have pursued." 80 ConG. ReC. 6310 (1936).

29. The next year, the Supreme Court in Helvering v. Gowran, 302 U.S. 238 (1937), used the same logic as in Koshland to tax the sale of dividend shares by attributing to them a zero basis-the original shares had already been sold using an allocated basis as the regulations had provided. The taxpayer was unable to use 1NT. REv. CODE OF 1954, §1311, because it was not enacted until 1938. Sce BITTKER \& EUSTICE If 7.6 0, at 7-62 n.109. 
The next phase of case law development concerned the 1936 stock dividend provisions reenacted in the Internal Revenue Code of 1939 and began with the Supreme Court decision of Helvering $v$. Griffiths..$^{30}$ This phase lasted until the 1954 Code revised the section by granting a general exemption for stock dividends with certain exceptions. The facts of Griffiths were the same generally as in Macomber-a common stock dividend to a common shareholder with no other classes outstanding. The Court held that the dividend was not taxable under section $115(f)(1)$ of the 1939 Codc. ${ }^{31}$ In reaching the conclusion that the enactment of section $115(\mathrm{f})(1)$ was not a congressionaI invitation to review Macomber, ${ }^{32}$ the majority emphasized the $\operatorname{mood}^{33}$ and uncertainty of Congress in the arca of stock dividends and the fact that the Koshland case had almost no impact on reshaping the final version of the 1936 Revenuc Act. The Court pointed to the regulation issued under the 1936 Act which, rather than repudiating Macomber, had exempted that type of stock dividend making a distinction between taxable and nontaxable stock dividends by defining the latter as those which worked "no change in the corporate entity-the same interest in the same corporation being represented after the distribution by more shares of precisely thc same character." ${ }^{34}$ Prior to Griffiths the Court had dccided Helvering v.

30. 317 U.S. 371 (1943).

31. Mr. Justice Douglas' dissent, joined by two other Justices, was critical of this and believed Eisner v. Macomber should be overruled. Id. at 409.

32. The Court quoted Congressman Vinson on the floor of the House with reference to $\S 115(f)(1):$ "In no sense is this an attack upon the Eisner against Macomber decision." Id. at 380. See also notes $25 \& 28$ supra.

33. The Court majority avoided the constitutional issue and concluded its argument by stating:

We think if Congress had passed or intended to pass an Act challenging a well known constitutional decision of this Court there would appear at least one clear statement of that purpose either from its proponents or its adversaries. Not one contemporaneous word in or out of Congress discloses the purpose which the Government says we should find that this legislation accomplished. 318 U.S. at 389.

34. Treas. Reg. 94, arts. 115-17 (1936) had three examples. Ex. I was a distribution of common on preferred with common and $7 \%$ cumulative preferred outstanding. This was deemed a taxable dividend since it fell within the broad scope of $\S 115(\mathrm{f})(1)$ and Koshland. Ex. 2 was a distribution of common on common with only common outstanding. This was not deemed a taxable dividend since it was squarely in point with Eisner v. Macomber. Ex. 3 was a distribution of preferred stock on its common shareholders at $1 / 10$ th share of preferred for cach common share. The outstanding stock was common and $7 \%$ cumulative preferred (with voting rights). The distribution was deemed taxable sinee the common shareholders would be receiving a disproportionate interest in the equity of the corporation. 
Brunn ${ }^{35}$ and Helvering v. Horst. ${ }^{36}$ The Court in Brunn upheld the tax on a lessor on the value of a building erected by the defaulting lessee and rejected the concept that taxable gain could arise only when the taxpayer was able to sever the economic gain from his original capital. The Horst case held that a father who clipped an interest coupon before its maturity date and gave it to his son had realized the income himself - the economic gain was enjoyed "by some event other than the taxpayers' personal receipt" of the money or property. ${ }^{37}$ These decisions revamped the Treasury's opinions on both the meaning of "income," and the continued vitality of Macomber, and became the motivating impetus for the ill-fated challenge by Griffiths of Macomber. ${ }^{38}$

Following Griffiths it was still far from clear which parties and what interests were to be affected by the Koshland ruling. The cases which followed involved a struggle between a strict and a liberal interpretation of Macomber. The strict view accorded tax exemption to the receipt of identical property only, taxing a stock dividend which gave the stockholder a different interest-in any way, shape or form -from what he held before. The liberal view extended the exemption to any distribution as long as the proportionate interests in the corporation were not changed. ${ }^{39}$

The strict interpretation was set aside by the companion cases of

35. 309 U.S. 461 (1940) (Mar. 25, 1940).

36. 311 U.S. $112(1940)$ (Nov. 25, 1940).

37. Id. at 116.

38. See also Surrey, The Supreme Court and the Federal Income Tax: Some Implications of the Recent Decisions, 35 lLL. L. Rev. 779 (1941), for a discussion of the concept of income from Eisner v. Macomber through Brunn. Eisner v. Macomber's detailed and thorough definition of income has heen affected by the subsequent cases which looked to it as the starting point. The realization principle at the end of 1940 was far different than that in 1920 and the passing years have even further expanded this area.

39. The Board of Tax Appeals had followed the proportionate interest test prior to Koshland and Gowran. See Pearl B. Brown, 26 B.T.A. 901 (1932), affd, 69 F.2d 602 (7th Cir. 1934) (preferred on common, no other class outstanding).

The Board then applied the stricter rule requiring precisely the same character of stock dividend. Frank J. Kelly Trust, 38 B.T.A. 1014 (1938) (a dividend of preferred on common, no other class outstanding); John M. Keister, 42 B.T.A. 484 (1940), rev'd sub nom., Sprouse v. Comm'r, 122 F.2d 973 (9th Cir. 194I), affd, 318 U.S. 604 (1943) (a dividend of nonvoting common on common shareholders, some having and others not having voting rights, only voting and nonvoting common outstanding). But note the Commissioner did not attempt to tax a distribution of nonvoting stock on nonvoting stock where voting common and preferred were also outstanding. 
Helvering v. Sprouse ${ }^{40}$ and Strassburger v. Commissioner. ${ }^{41}$ In Sprouse, the Court held that a dividend of nonvoting common equally distributed to holders of voting and nonvoting common, both classes being outstanding, was not a taxable distribution. Originally owning only voting common, neither the taxpayer's voting rights nor dividend liquidation rights were altered by the receipt of nonvoting common. The dividend in Strassburger was of a newly created issue of nonvoting cumulative preferred or common, with only common outstanding and all owned by the taxpayer. The dividend was nontaxable; all incidents of ownership and the same net value were possessed by the taxpayer both before and after the distribution. ${ }^{42}$

The use of preferred stock in what is commonly called a "bailout," accumulated earnings capitalized and distributed as preferred stock, became a distinct possibility after Sprouse and Strassburger. However, the bailout was seldom utilized because the Treasury Department refused to issue favorable rulings. The risks were too great since a large portion of the bail-out would be lost in a successful Treasury case. The taxpayer was successful, however, in Chamberlin v. Commissioner, ${ }^{43}$ the most famous case highlighting the preferred stock bail-out. After Chamberlin the law of stock dividends was in disorder and the means seized by the 1954 Congress was to alter the

\footnotetext{
40. 318 U.S. 604 (1943).

41. Id.

42. The litigation in this area was not terminated because there remained additional questions which had to be answered. These revolved around which distributions were to qualify as tax free and more especially the factors affecting the operation of the proportionate interest test. See Schmitt v. Comm'r, 208 F.2d 819 (3d Cir. 1954); Wiegand v. Comm'r, 194 F.2d 479 (3d Cir. 1952); Tourtelot v. Comm'r, 189 F.2d 167 (7th Cir. 1951); Pizitz v. Patterson, 183 F. Supp. 901 (N.D. Ala. 1960); John A. Messer, 20 T.C. 264 (1953). See also Edwin L. Wiegand, 14 T.C. 136 (1950), as noted in 50 ColuM. L. Rev. 999 (1950); 65 HARV. L. REv. 1248 (1952); 49 Mich. L. Rev. 297 (1950). Though the new section 305 returns to the "proportionate interest" test, it has overcome some of the prior problems because of the limited occasions when they may arise. This was accomplished by categorically delineating specific areas in the statute and granting broad regulatory powers.

It has been stated with some degree of vigor that at least six Justices in 1943 must have thought it was constitutional to tax the stock dividends involved. See S. SURREY \& W. WARREN, supra note 6, at 1296; Lowndes, supra note 11; Rottshaefer, supra note 11.

43. 207 F.2d 462 (6th Cir. 1953), cert. denied, 347 U.S. 918 (1954). This case dealt with a preferred stock dividend on common, the only class outstanding. A few days after the distribution the preferred (possessing mandatory retirement in the future as long as earnings and profits existed) was sold to an insurance company (hence capital gain), prior negotiations having been held. The Court considered each step as properly leading to a result equated to Eisner v. Macomber. Compare Comm'r v. Court Holding Co., 324 U.S. 331 (1945); Gregory v. Helvering, 293 U.S. 465 (1935).
} 
prior general rule. The new general rule exempted stock dividends from classification as income. ${ }^{44}$ The two exceptions to the general rule were preference dividends and the option to elect distributions in lieu of money ${ }^{45}$ The preferred stock bail-out was dealt with in a new section, section 306, which taxed the tainted stock as ordinary income ${ }^{46}$ at the point of sale, or as a section 301 dividend at redemption. ${ }^{47}$

Soon after enactment of the 1954 provisions it became apparent that various techniques were available, and more could be devised, to circumvent the exceptions of section 305 . The shareholders, by creating two classes of stock, one class receiving stock dividends, the other cash, could be provided with a choice, or election, to receive dividends of cash or stock and yet not be taxed on the stock distribution. Another means of escape was the use of convertible preferred stock which had annual increases in its conversion ratio or redemption price while the cash was retained. To combat some of these new techniques, the Treasury issued proposed rcgulations in 1956 which utilized the 305 (b)(2) election theory and were aimed at the disguised elections. ${ }^{48}$

44. INT. REv. CODE of 1954, § 305(a). The Senate Committee Report said, "As long as a shareholder's interest remains in corporate solution, there is no appropriate occasion for the imposition of a tax. Accordingly, the general rule is that no tax is imposed upon the distribution of stock rights and stock dividends whether or not a particular sharehoider's proportionate interest in the corporation is varied, but rather is postponed through the application of the pertinent basis provisions." S. REP. No. 1622, 83d Cong., 2d Sess. 44 (1954).

See also $\S 307$, which allocates the basis between the dividend stock and the old stock in proportion to values, and $\S 312$ (d) which provides for no reduction in earnings and profits for tax free distributions.

45. The exemption-granting provision of section 305(a) was concerned with distributions "with respect to its stock" which did not include those shareholders who were creditors, vendors, or employees. The distributions of stock were to be its own stock including treasury stock, rights to treasury stock, or unissued stock and did not include debt instruments or purported stock found to be debt. BitTKER \& Eustice $\mid$ I 4.02-.22, 7.61, gives an in-depth analysis, especially of the stock versus debt classification.

46. INT. REv. CODE OF 1954, \& 306(c) defines the tainted stock.

47. See S. ReP. No. 1622, 83d Cong., 2d Sess. 46 (1954) for remarks re preferred stock bail-out and $\S 306$.

48. Proposed Treas. Reg. $\$ 1.305-2,21$ Fed. Reg. 5104 (1956). The legal strength of the 1956 proposed regulations was seriously doubted, even though they did exert a considerable restraining force. The Treasury's theory in the regulations could have been that the election occurred upon buying or taking one or the other of the two classes, not in taking cash or stock. See Proposed Treas. Reg. $\$ 1.305($ b)(2), Ex. 2, 21 Fed. Reg. at 5105.

See also Eustice, Corporations and Corporate Investors, 25 TAX L. REv. 509, 537 \& 539 (1970); Lubin \& Moorehead, Stock Dividend Benefits Restricted But Not Eliminated by the New Tax Law, 32 J. TAXATION 258 (1970); Ray, Stock Dividends: Section 305(b) and the Conglomerates, 21 S. CAL. INST. 341 (1969). 
Under the regulations an "election" occurred when there were two classes of stock outstanding, some shareholders received cash or other property and some received stock, and at some point a shareholder exercised or permitted a choice which allowed the distributions. ${ }^{40}$ Though these regulations were never finalized,,$^{50}$ they were reproposed in $1968^{51}$ in greatly expanded form and were then finalized ${ }^{52}$ in 1969 , in basically the same form as proposed with a slight easing of the preference dividend, antidilution and contingent stock, and transition rules.

The 1969 regulations presented several new rules or principles for the taxpayer to cope with. First, the two class common stock plans, pursuant to an $(E)^{53}$ recapitalization, created an election because of the stockholder's availability to exchange stock tax-free under section $1036 .{ }^{54}$ Second, another method of creating a second class of stock

49. The 1956 House Advisory Group Report on Subchapter $C$ noted the Citizens Utilities problem and the proposed regulations' efforts toward containment. It recommended adding a sentence to original section 305(b) whereby a 305(a) distribution, in respect to one or more classes of common, payable in stock (or rights) to some shares and property to the remainder, would be outside 305(a). A new Advisory Group Report, issued in 1957, advised adding a new subsection 305(b)(3) and a return to the proportionate intercst test of pre-1954 law, so as to tax stock dividends which had the effect of increasing the stockholder's proportionate interest. House Ways and Means Committee, Advisory Group Report on Subchapter C $492-93$ (Dec. 24, 1957). The Advisory Group in effect disapproved of the statutory interpretation of the 1956 proposed regulations and specifically alluded to the 1954 congressional intent of liberalizing the non-taxation of stock dividends. No finalization of the 1956 regulations took place and the only Treasury information seemed to be T.D. 6476, 1960-2 CUM. BULL. 111, stating that further consideration of the proposed regulations was necessary.

50. The 1956 proposed regulations, based on the 1954 section 305(b)(2) clection theory, gave some hint of the possible expansive use they could have had by using additional and more comprehensive words. Thus, the election could apply whether the election of "option" were exercised "or exercisable" before or after the declaration of the distribution. Proposed Treas. Reg. $\S 1.305-2(a)(2), 21$ Fed. Reg. 5104 (1956). The opinions of the tax bar ranged from accepting the 1956 proposed regulations as limiting Citizens Utilities recapitalizations, through confusion, to outright contradiction. See Haddad, Two-Class Common (Citizens Utility) Stock Plans Would Be Killed by Change in Law, 9 J. TAXation 71 (1958); Lee, The Stock Dividend, 27 TAXEs 959, 972 (1959); I.R.S. Attempts to Stop 2-Classes-of-Common Tax Saving Plan; Legality Questioned, 5 J. TAXATION 178 (1956).

51. Proposed Treas. Reg. $\S \S 1.305-2,1.305-3,33$ Fed. Reg. 12744 (1968).

52. Treas. Reg. $\S 1.305-2,1.305-3$, as amended by T.D. 6990, 1969-1 CUM. BuLL. 95, and T.D. 7004, 1969-1 CUM. BULL. 97.

53. INT. REV. CODE OF 1954, § 368(a)(1)(E). Forms of $\S 368$ reorganizations will be referred to by their $\S 368(\mathrm{a})(1)$ letter designation.

54. The explicit reference to section 1036 was not in the 1956 proposed regulation. The examples and wording were nearly the same for this area in 1956 and were finalized in 1969. Treas. Reg. $\S 1.305-2(b)(1)$, third sentence, expanded the definition to refer to the point in time of the choice. It was now immaterial whether it was before or after the declaration, as long as "by action or inaction" the "choice," or continuance of ownership as it were, was made which thereby allowed the corporate distribution. See also Treas. Reg. § 1.305-2(b)(2), Exs. 1 and 2. 
could result pursuant to a (B) reorganization whereby a second class was issued and the periodic conversion ratio of the original stock was increased as cash dividends were paid on the new stock. When the conversion ratio of original stock increased to affect its cash dividend, the new stock fell within the election theory of a stock dividend. The stockholders of the original class could be similarly taxed on the periodic decrease of the new class of stock when it received the cash dividend.$^{55}$ Third, the preference dividend rules of original subsection 305(b)(1) were broadened by defining preferred stock, for this purpose, as stock that was in all events required to receive annual distributions of stock or rights, ${ }^{56}$ taxing the stock distribution without the need of any cash counterpart. The same result was obtained when the conversion ratio between two classes was automatically increased irrespective of any distribution. The stock class receiving greater shares in conversion after the increase was deemed preferred since section 1036 could be utilized. ${ }^{57}$

These regulations did not reach a number of other methods available for circumventing the Treasury's goal. Annual redemptions of a stated percentage of each shareholder's shares was a possibility, as was an annual, but cumulative and presently nonpayable, increase in the conversion ratio, or a dividend waiver in exchange for an initial receipt of a greater number of shares. The brunt of the regulations policy change was to at least intimidate if not effectively restrict the use of convertible preferred or convertible common stock by the conglomerates, which at this time were coming under varying forms of sharp criticism..$^{58}$

The 1969 regulations though, could not include the relatively simple situation of a common stock dividend upon common stock, where convertible preferred is outstanding and receiving cash dividends but without an increasing conversion ratio. This situation could not fit under either the original subsection $305(\mathrm{~b})(1)$, since the stock dividend

55. Id. at Exs. 3 and 4.

56. Treas. Reg. § 1.305-3(b)(2), Ex. 1.

57. Id. at Ex. 2.

58. The Treasury could use this approach in almost any reorganization regardless of the subsection 368(a)(1) sublettering form chosen. See BITTKER \& EUSTICE on possible use of step transactions in reorganizations and substance over form. See generally Eustice, supra note 48; Levin, New 305 Reg. Limit Tax Advantages of 2-Class Common Stock, But Alternatives Exist, 30 J. TAXATION 2 (1969); Ray, supra note 48, at 358. 
was not required, or (b)(2), since the common could not be exchanged tax-free with the convertible preferred under section $1036 .{ }^{59}$

\section{The New Statute}

The Tax Reform Act amendments to section 305 form the latest major step in the history of stock dividends and their taxability. Section 305 has not only been expanded to reach five specific exceptions to the general rule of exemption, it has also granted sweeping regulatory powers to the Treasury.$^{60}$ The nearly complete revision has seemingly restricted the use of most substitute transactions yielding a disguised dividend. The corresponding emergence and growth of the general tax case law, especially in the past half century, has also made its mark and been assimilated.

Section $305(a)^{61}$ continued the original 1954 exemption from gross income of all stock dividends or rights, unless otherwise provided for in the section $305(\mathrm{~b})$ exceptions which treat all transactions within their purview as section 301 distributions at the time of distribution. ${ }^{62}$ Subsection 305(b)(1) continues the 1954 Code exception of the election by any shareholder, thereby affecting all, of stock or property; 305(b)(2) prevents one or more disproportionate distributions;

59. The final regulations effectiveness was questionable on other grounds as well. The most important of which were the limits or definition of Reg. $\S 1.305-2$ (b)(1)'s parenthetical "or series of distribution," and also the extension of the original statutory base of section $305(b)(2)$ 's election provision to include a choice fulfillment by inaction, hence taxation of a possible nonrealization of income. Other problems revolved around the definition of common stock or what factors made a stock preferred, valuation, and retroactivity. See generally Treas. Reg. $\S \S 1.305$ 2(b), 1.305-3(b). The final 1969 regulations were relaxed slightly by permitting a three year exemption after issuance on conversion increases of preference dividend discharges, by not applying the new definition of preferred stock to delayed issues in a contingent consideration reorganization, and by including somewhat liberal (to 1991) transition rules for stock outstanding or subsequently issued via a binding written contract. September 8,1968 , the date of the promulgation of the proposed regulations, was the cut-off date.

60 . It is interesting to note the similarity in approach now taken by $\S \S 305 \& 1221$, defining capital asset, i.e., the broad inclusion followed by limiting statutory and case exceptions.

61. INT. REv. CODE OF 1954, § 305(a).

62. For the purposes of this article unlimited earnings and profits are assumed unless otherwise stated.

Subsection 301(a) refers to $\S 301$ (c) for the amount taxable and $\S 301$ (b) for the amount distributed, to $\S 301(b)(1)(A)$ for noncorporate distributees and $\S 301(b)(1)(B)$ for corporate distributees. If the election exception of $\S 305$ is utilized the Regulations confer varying amounts in distribution, see Treas. Reg. $\S 1.305-2(\mathrm{c}) \& \S 1.301-1$ (d); BITTKER \& EUSTICE If 7.61. Subsection 301 (c)(1) includes in gross income that portion of the distribution which is a dividend, $\S 316(\mathrm{a})(1)$ and (2) define dividend as all earnings or profits present or accumulated from 1913. The excess is treated as a reduction in basis and any amount beyond that receives capital gains treatment. 
305(b)(3) attacks distributions of both preferred and common to common shareholders; $305(\mathrm{~b})(4)$ taxes distributions on preferred stock; and $305(b)(5)$ reaches most distributions on convertible preferred stock. Section 305(c) empowers the Treasury to interpret by regulation the definitive scope of transactions having a disproportionate result or effect on the equity interests of any shareholder and to treat such transactions as constructive stock dividends-thereby directly adding and enlarging the scope of subsections 305(b)(2) through (b)(5). Section 305(d) completes the new provisions by defining rights to acquire stock as stock, and defining a shareholder as including a holder of rights or convertible securities.

The tax consequences of many transactions are now questionable due to the extraordinary scope of the new stock dividend section. Some of the more general problems would include the definitions of "serial" distributions and common and preferred stock, the need for two "distributions," even if one is constructive via section 305(c), and the dispute as to the necessity of a nexus between the distributions. On a more philosophical plane are the questions of the improper delegation of legislative powers, the extent to which reorganization-nonrecognition provisions are superseded by section 305 (c) and, above all, the continued vitality of Eisner v. Macomber. The heart of section 305 is its persistent attempt to reach and currently tax the stockholder who has "elected" to receive equity appreciation in lieu of cash or who allows the same result to occur without any action on his part.

\section{Analysis}

Subsection 305(b)(1) continues the old 305(b)(2) exception that a stock dividend is a section 301 distribution to all receivers where any shareholder has exercised an election to receive stock instead of money or other property. The scope of subsection $305(b)(1)$ should be narrower since many transactions formerly under $305(\mathrm{~b})(2)$ are now covered by the other exceptions in 305(b) and 305(c). The House and Senate committee reports merely mention its reenactment with no further discussion or interpretation. ${ }^{63}$

The most important amendment to the stock dividend rules is the subsection 305(b)(2) disproportionate distribution exception which

63. H.R. ReP. No. 413 , at pt. I, at 113; S. REP. No. 552, at 152. See also note 23 supra. 
has the sometime help of section 305 (c) ${ }^{64}$ Subsection 305(b)(2) states that the distribution of stock; or rights, will be taxed if the distribution, or a series of distributions of which such a distribution is a part, results in the receipt of money or other property by some shareholders and an increase in the proportionate interests in the assets or earnings and profits, or equity, of the corporation by others. These must necessarily be two separate distributions, one of money or other property to some shareholders, and the other distribution being a stock dividend, whether actual or constructive, to other shareholders. The Senate Finance Committee had provided for a de minimus exception to subsection 305(b)(2) to apply where a corporation did not wish to distribute fractional shares. ${ }^{65}$ This exception was needed because even the smallest cash payment would make an entire stock distribution disproportionate. While the Conference report omitted this saving provision from the final bill, a Treasury decision ${ }^{66}$ sanctions cash distributions in lieu of fractional shares, provided the purpose of the cash distribution is to save the corporation the trouble, expense and inconvenience of issuing fractional shares and not to give any particular group of shareholders an increase in their proportionate interests.

The major interpretative problems of subsection 305(b)(2) revolve around the meaning of "series," "result of," "proportionate interests," and the connecting "and" between subsections $305(\mathrm{~b})(2)(\mathrm{A})$ and $(b)(2)(B)$, or the nexus between the distributions. A hypothetical problem will illustrate that there are distributions of stock which are not taxable. It shall be assumed throughout all of the hypotheticals that the corporations have unlimited earnings and profits and all the distributees are individuals. Also, the distributions may be of stock or rights to stock, and are pro rata unless otherwise stated.

Problem I. This involves a distribution of common stock on common stock by corporation $X$. The outstanding stock consists of a single class of common and a class of nonconvertible preferred paying

64. Section 305 (c) grants broad statutory authority to the Treasury to prescribe regulations for the treatment of transactions which are effectively disguised stock dividends. The Treasury is specifically empowered to promulgate regulations "under which a cbange in conversion ratio, a change in redemption price, a difference between redemption price and issue price, a redemption which is treated as a distribution to which section 301 applies," or generally where "any transaction (including a recapitalization) having a similar effect on the interest of any shareholder" occurs and to treat this effect as if it were a disproportionate distribution which increases the proportionate interest in the earnings and profits or assets of the corporation.

65. S. REP. No. 552, at 154.

66. T.D. 7039, 1970-1 Cum. Bull. 67. 
cash dividends. The receipt of a cash dividend by the preferred stockholders and the stock dividend by the common holders within six months of each other seems to fulfill the two distribution requirements. However, there is no disproportionate distribution because the preferred is not convertible; thus, the general rule of section 305(a) exempts the common stock received by the common stockholders from taxable income. ${ }^{67}$

There would seem to be a requirement of a contemporaneous time link between the two distributions before there would be "disproportionate distribution" under subsection 305(b)(2), although none is present in the statute itself. The Treasury explanation of disproportionate distributions stated that "for purposes of this exception, a distribution would be considered to be made in conjunction with another distribution if it is made within 12 months of the other or if both are made pursuant to a single plan." 68 The two distributions in Problem I, being six months apart, then, would satisfy the connection in time requirement; in fact, all of the Treasury examples use a six month time span between distributions. ${ }^{69}$

The common stock distribution in Problem I was a single distribution. If a number of distributions had been occurring for several years it could be argued that none, part or all should be included in "the" distribution. It seems, however, that a well-grounded argument is available to a taxpayer to limit the period of such inclusion by using the Service's own regulations and case arguments in the reorganization area ${ }^{70}$ Thus, the inclusion of only the activity occurring within a

67. This particular example was used by the House and Senate committee reports and the Treasury explanation before the House. H.R. REP. No. 413, at 113; S. REP. No. 552, at 152; 1969 House Hearings pt. 14, ex. 2, at 5195.

The Treasury Proposals technical explanation examples before the House are hereinafter referred to as the "Treasury examples."

68. 1969 House Hearings 5194. The Senate Committee Report, S. ReP. No. 552, at 152, refers to this by saying "corresponding stock dividends," while the House report, H.R. REP. No. 413, at 113, makes note of "stock dividends equated to." The two distributions in Problem I, being six months apart, then, would satisfy the connection in time requirement.

69. 1969 House Hearings Exs. 1-3 at 5194-95.

70. Treas. Reg. $\S 1.368-2$ (c) describes the qualifying rules for a (B) type reorganization where it states:

the acquisition of stock of another corporation by the acquiring corporation solely for its voting stock is permitted tax-free even though the acquiring corporation already owns some of the stock of the other corporation. Such an acquisition is permitted tax-free in a single transaction or in a series of transactions taking place over a relatively short period of time such as 12 months. 
twelve month time period in a single transaction, recurringly used by the Service, might be developed as a general rule, or form an estoppel. ${ }^{71}$

Problem II. Here there is a distribution by corporation $\mathrm{X}$ of its common stock to some common shareholders followed by a cash distribution six months later to the other common shareholders, no other classes of stock being outstanding. Since the distributions are considered to be related and since the stock dividend owners have increased their proportionate interests in the equity, the stock distribution is a section 301 distribution by virtue of section $305(\mathrm{~b})(2)$.

While the alternative ground of subsection $305(\mathrm{~b})(1)$ might be used to reach the distribution, the question of an "election" by inaction could be argued by the taxpayer. This would be especially true should there be two classes outstanding, one receiving cash dividends only and the other receiving stock dividends only. Since the transaction clearly fits under subsection 305 (b)(2) there is little need to make the election argument. ${ }^{72}$ If cash dividends are waived for stock dividends by some shareholders, however, while others receive the stock dividends, the result would be taxation via subsection 305(b)(1)'s election theory. If the cash dividends were waived for stock dividends, and other shareholders were receiving cash dividends, the stock dividends would be taxable as a disproportionate distribution. The best advice in this type of situation seems to be a complete waiver of both cash and stock dividends to avoid taxation. However, a double waiver may be some form of election, realization or gift, especially if the majority waives and the minority are children of the majority. ${ }^{73}$

The shareholders in Problem Il who received stock dividends increased their "proportionate interests . . . in the assets or earnings and profits of the corporation."74 For simplicity, if we assume that

71. Whether the final time period be twelve, twenty-four, or thirty-six months, the above described twelve month period used by the Treasury and applicable to (B) reorganizations has argumentative worth. As to this, see also American Potash \& Chem. Corp. v. United States, 399 F.2d 194, reheard and rem'd, 402 F.2d 1000 (Ct. CI. 1968).

72. Treasury example one is the duplicate of Problem 11 above and only describes this transaction as a disproportionate distribution of subsection $305(b)(2)$.

73. See Helvering v. Sprouse, 318 U.S. 604 (1943); Harrison v. Schaffner, 312 U.S. 579 (1941); Helvering v. Horst, 311 U.S. 112 (1940); Helvering v. Clifford, 309 U.S. 331 (1940). Rev. Rul. 58-337, 1958-2 Cum. Bull. 13; INT. REv. CODE of 1954, §§ 671-78 (grantors and others treated as substantial owners). See generally Perlman v. Feldman, 219 F.2d 173 (2d Cir. 1955); Lyon \& Eustice, Assignment of Income: Fruit and Tree as Irrigated by the P.G. Lake Case, 17 Tax L. Rev. 295 (1962).

74. INT. REv. CODE OF 1954, § 305(b)(2)(B). 
corporation $\mathrm{X}$ is equally owned by only two shareholders, $\mathrm{A}$ and $\mathrm{B}$, then a distribution of stock to A, and cash to B, will result in A's possessing greater than the $50 \%$ he did prior to the distribution. The increase in this case is in the ownership or equity of the corporation and has a distinct monetary value. The value of this increase in A's ownership is the value of the newly distributed shares, which, presumably, is the same value as the cash distributed to B. After the distribution, A's interest in the assets has increased, since A would receive a greater share in liquidation. The interests in the earnings and profits are also increased since any cash dividends would be distributed according to ownership of common shares. Problem I revealed that its common stockholders were not placed in a position of a greater or lesser percentage ownership by their receiving common stock and the preferred stockholders receiving a cash distribution. Even a series of such distributions would have no disproportionate effect, but would be similar to the pure Macomber type of distribution.

The 1969 regulations promulgated under the 1954 section $305^{75}$ were a Treasury attack on a distribution of an earnings and profits cash dividend in the form of a protected stock dividend rather than a mere capital growth or accretion to value distribution. The election exception of subsection $305(b)(1)$ was expanded out of necessity to include what had been termed a disproportionate distribution prior to 1954. The question arises, therefore, as to the applicability of pre-1954 law or theory under the new section 305 , and more pointedly, what factors presently affect and increase the interest in the assets or earnings and profits of a corporation.

The Treasury examples use exceptionally simple fact patterns and do not particularly deal with the problem as it existed prior to 1954 . Three of the five Treasury examples employ fact patterns with only one class of stock outstanding and distributions or redemptions of additional shares of the same class. The other two examples are equally unvaried, one having an additional preferred class and the other having two "types" of stock..$^{76}$ The more common factors which had affected shareholder interest under the 1939 Code were dividend, liquidation and voting rights. ${ }^{77}$ Although any change in these rights within the class or between two classes of stock would seem to be

75. See T.D. 6990, 1969-1 Cum. BuLl. 95.

76. 1969 House Hearings 5194-95.

77. See Rottschaeffer, supra note 11, at 120. 
sufficient to constitute a change in interests, the form of a right increasing the interest is not as limited as the Treasury examples indicate. For example, there are usually two general classes of stockcommon and preferred-which may each possess certain additional rights. This will be especially true with the preferred which may have a preference in liquidation, dividends or assets; participation or nonparticipation; cumulation or non-cumulation; redemption or convertibility; and par or non par-value. Granting any of these rights to less than all of the shareholders could arguably be a disproportionate distribution.

Tourtelot $v$. Commissioner ${ }^{78}$ and Wiegand $v$. Commissioner ${ }^{79}$ reveal that the seventh and third circuits took a very limited view of what changed a stockholder's interest. The Tax Court and an Ala-

78. 189 F.2d 167 (7th Cir. 1951). The corporation had outstanding 4000 shares of Class $A$ common (100 par value per share) and 24,000 shares of Class B common (no par value, only stated value of $\$ 5$ per share). The Class $A$ stock was in reality a preferred stock with numerous rights (including accumulation, all voting, liquidation, and dividend participation). The distribution consisted of a $50 \%$ dividend of Class B to B shareholders. In the Tax Court the Service conceded no immediate change in the proportionate interests, but argued that the test should look to the change in the corporation as a going concern; (i.e., control in the corporation, dividend and liquidation values). The Tax Court, citing new annual obligations of $\$ 36,000$ versus obligations of $\$ 24,000$ before the distribution, agreed with the Service.

The court of appeals reversed, reasoning that in toto the new advantages of Class $A$ were offset by the disadvantages of Class B, since the taxpayers in question owned 2 percent of each class- "the same total interest in the corporation as before the dividend was declared." I Il. at 169.

79. 194 F.2d 479 (3d Cir. 1952). The stock dividend distribution was similar to Tourtelot but with different stock dividend recipients. Wiegand had been argued on May 8, 1951 but was reargued on December 7, 1951 because the seventh circuit decision had been decided on May 28, 1951. The third circuit had at first imposed taxation, because these stockholders did not own precisely the same interests in the corporation before and after the distribution. On rehearing the third circuit held no taxable dividend. After a brief summary of the history and applicable law the court (per Chief Judge Biggs) quoted Mr. Justice Holmes in Towne v. Eisner: "In sbort, the corporation is no poorer and the stockholder is no richer than they were before [the stock dividendl." Id. at 481 . The Chief Judge continued by declaring that the theory of retention of capital was a closed circle doctrine, and that "these [stock dividends] were practical, money-wise changes as distinguished from alterations of rights." Id. at 481 . A footnote to the case presented the alternative argument that each old A stock shareholder received dividends in preference to the B stock shareholders, and each new A certificate affected a strict legal right of the B certificates. This argument was rejected by the court which improperly expanded the questionable Tourtelot theory to the corporation as a whole. "It is true following the distribution that the B stock cannot receive its dividend until what now is more of the A stock has received its dividends. But the legal rights of the $A$ and $B$ have not been changed or affeeted . . . [T]he B stock, after the distribution, will eat lower down on the hog, but the hog has grown. The cuts, the proportional interests, of the A and the B remain the same." Id. at 481 n.3. This Court would doubtless rarely find a taxable stock dividend. 
bama District Court in John A. Messer v. Commissioner ${ }^{80}$ and Pizitz v. Patterson, ${ }^{81}$ on the other hand, imposed taxation after a seemingly more rational and reasonable inquiry. In Tourtelot, the court of appeals reversed the Tax Court's finding of a disproportionate distribution because the taxpayers' total interests, each owning two percent of each class of outstanding stock, were not affected by the distributions, even though the one class, in reality a preferred stock, gained what the other lost. In Wiegand, the same case was presented, but with taxpayers not owning the same percentage of the two classes. The third circuit also rejected taxation by declaring no changes were affected in the strict legal sense of stockholders vis-a-vis each other or the corporation. The court simply declared that, as to the whole corporation, no interests had been affected.

In Messer, the dividend was of preferred on preferred, with common and preferred outstanding. The preferred had a cumulative five percent dividend and liquidation preferences. The taxpayer was found by the Tax Court to have received a taxable stock distribution since he increased his ownership of preferred stock from sixteen percent to twenty-two and one-half percent. In Pizitz, on basically the same facts, taxation was again upheld by the district court. Here there existed dividend and liquidation rights which were altered between the shareholders.

The district court in Pizitz explained that the rights to look at were the dividend, liquidation and voting rights. Even though the reasoning of Tourtelot and Wiegand is doubtful, they must be reckoned with, especially in view of the fact that the Treasury examples do not really deal with this particular area. If logic were to prevail, it seems that almost any form of distribution which will have the effect of

80. 20 T.C. 264 (1953). The stock dividend was of preferred on preferred, with common and preferred (cumulative $5 \%$ dividend and liquidation preferences) outstanding. All common shareholders owned some preferred, but some preferred stockholders owned no common. The percentage of common owned was not equal to the percentage of preferred owned. Taxpayer here owned $72 \%$ of common and $16 \%$ of preferred. The preferred distributed was from the outstanding shares and after distribution the taxpayer had greater rights relative to the corporate enterprise, as his ownership of preferred rose from $16 \%$ to $22.4 \%$.

81. 183 F. Supp. 90 I (D. Ala. 1960). The stock dividend was preferred on common, with both common and preferred outstanding (preferred as to cumulative dividend, and in liquidation). The taxpayers were husband (who owned only common prior to dividend) and wife (who owned both classes prior to dividend). The court felt the problems of interest should be decided on a case by case basis, and that the rights to consider were dividend, liquidation, and voting. On the facts in this case, the court held proportionate rights upon liquidation and to dividends were altered by the distribution-hence, taxable. 
varying these rights in the future is a disproportionate distribution. It is, therefore, clear that the theory of Messer and Pizitz will probably be pressed by the Treasury. This would appear to be within the intent of Congress; in fact, the enactment of section 305 in 1969 seems to be an indirect statement by Congress that they desire to include every stock dividend as taxable income except those of the pure Eisner $v$. Macomber strain. The question of what affects the "interests" under the new section 305 is now related to the substantive question of the propriety of taxation on an illusory dividend or non-dividend which may result by use of section 305(c)'s constructive distribution in conjunction with subsections $305(\mathrm{~b})(2)$ and (b)(4). The following problems will illustrate the application of section 305 (c).

Problem III. Here concern is directed toward a constructive dividend resulting from an increasing conversion ratio. Corporation $\mathrm{X}$ has two types of stock outstanding, type A and type B. Each share of type B may be converted at the option of the holder into type A. At the beginning of each year the conversion ratio of $A$ is increased by .05 shares of $A$ for each share of $B$. Thus, at the beginning of the next year the ratio will be 1.05 of $A$ for each $B$ and in 2 years 1.10 of $A$ for each B. When a cash distribution is made to the A shares at the end of the year, December, and shortly thereafter, January, the conversion ratio of $\mathrm{A}$ is increased, the increase of .05 shares of $\mathrm{A}$ is constructively considered as distributed to each share of B via section 305(c). Since the two distributions are considered to be related and the proportionate interests of the B shareholders are increased, the subsection 305(b)(2) exception imposes taxation on the right to acquire the additional .05 shares..$^{82}$

Problem III is an example of what the 1969 Regulations had sought to tax as an election, passive though it may be, by B shareholders due to their tax free convertibility. ${ }^{83}$ The new code provisions, giving congressional support to the 1969 Regulations, have taken even greater steps to tax other forms of distributions or arrangements by which cash dividends were paid to some shareholders with corresponding increases in the proportionate interests of other shareholders. The House and Committee reports cited two areas in particular,

82. The same result would hold true if type B were a convertible preferred. If this were the fact pattern, section $305(\mathrm{~b})(4)$ would also tax the preferred and the Commissioner would scem to have his choice of section $305(\mathrm{~b})$ exceptions.

83. See 1969 House Hearings Ex. 3, at 5195; Trcas. Reg. $\S 1.305-3(\mathrm{~b})(2)$, Ex. 2. 
the periodic redemption plan, Problem IV below, and disguised forms of distributions on preferred stock-for example, a higher redemption than issue price. ${ }^{84}$

Problem IV. This involves a periodic redemption plan, where corporation $\mathrm{X}$ has one class of common outstanding, owned equally by $C$ and $D$, and, pursuant to a plan authorized by the board of directors, $\mathrm{X}$ offers to redeem up to five percent of each shareholder's stock annually. If shareholder $\mathrm{C}$ elects to redeem, the distribution would be essentially equivalent to a dividend under section 302(b)(1) and D's interests would be disproportionately increased. D would be taxed by $305(\mathrm{~b})(2)$ as receiving a subsection $305(\mathrm{~b})(2)$ (B) distribution, constructive under section $305(\mathrm{c})$, while $C$ received property in a distribution related in time and causing an increase in the proportionate interest of D. ${ }^{85}$

The Senate Finance Committee stated its opinion that "a thirty percent shareholder would not be treated as receiving a constructive dividend because a seventy percent shareholder causes a corporation to redeem fifteen percent of its stock from him." 86 This indicates that the regulatory authority was not intended to bring isolated redemptions of stock under the subsection 305(b)(2) exception, but was to apply only to a periodic redemption plan. There also exists a factual question as to what constitutes a periodic redemption "plan." The Treasury example specifically uscs a plan authorized by the board of directors, and anything less than that will certainly not present as strong a case ${ }^{87} 1 \mathrm{lt}$ seems that a redemption practice of reasonably long standing would also invoke taxation, although this will probably be decided on a case by case basis.

Problem V. Here there is a decreasing conversion ratio in one class of convertible stock resulting, upon receipt of cash, in a constructive stock dividend to the other class. ${ }^{88}$ Corporation $\mathrm{X}$ has two types of stock outstanding, type A owned by E, and type B owned

84. H.R. REP. No. 413 , at 113 ; S. REP. No. 552 , at 151 .

85. Though the new statute is dependent on the constructive distribution, it is not able to use the same distribution twice. Thus, a redemption distribution of property which is a constructive stock dividend via section 305 (c) is not to be used again as the section $305(\mathrm{~b})(2)$ (A) property distribution invoking section 305(b)(2). See Eustice, supra note 48, at 546-47.

86. S. REP. No. 552 , at 153.

87. See 1969 House Hearings Ex. 1, at 5197.

88. Id. Ex. 2, at 5197-98. 
by $\mathrm{F} .{ }^{89}$ The $\mathrm{B}$ stock is convertible into A stock, and the B convertibility ratio is decreased at the end of each year by one percentage point for each dollar of cash dividend paid to B shareholders. Thus, if $\$ 5$ is paid on B stock during the year the conversion ratio is reduced to .95 shares of $\mathrm{A}$ for each share of $\mathrm{B}$ converted. The reduction in the ratio is treated as a redemption by $F$ of A stock-type B treated as if it were type A since it is convertible-which increases the proportionate interest of $\mathrm{E}$. $\mathrm{E}$, then, is constructively deemed to have received a distribution of A stock. The cash received by $F$ through the constructive redemption is related to the constructive stock distribution which has increased the proportionate interests of $\mathrm{E}$. The Treasury adds to these two constructive transactions by valuing the gain to the shareholders as "the amount of stock that would have been required to be distributed to such shareholder immediately before the redemption in order to give such shareholder the same increase in proportionate interest." 90

The last three Problems ${ }^{91}$ have increasingly solicited the query as to the propriety of imposing taxation at the particular point in time disclosed by the new section 305 . The significant issue involves the regulatory power of section 305 (c) permitting a transaction to "be treated as" a distribution which increases the proportionate interest. This proportionate interest increase is thereby immediately taxable to the owner as if it were a section 301 dividend distribution. The taxpayer may have been better off to receive section 306 status, since that taxation is imposed at the time of disposition and not when constructively received.

\section{Judicial Review and Constitutional Ramifications}

In the first year that the federal income tax was enacted, 1913, the Treasury attempted to tax all stock dividends as ordinary income in the year of receipt. Since then the law has been a series of actions and

89. As in Problem IV, the type B stock could have been specifically called convertible preferred. For the sake of simplicity, a discussion of the use of preferred stock has been deferred until the end of the article where the technique employed by distributions of or on preferred stock will be dealt with as a unit. Especially significant are the non-distribution constructive dividends possible with $\S 305(\mathrm{~b})(4)$, and the taxable stock dividends resulting from intcrest payments on convertible securities.

90. 1969 House Hearings 5196.

91. A constructive disproportionate distribution increasing the equity will also be deemed where there is a difference in redemption price greater than issue price. 
reactions among the Treasury, the courts and the Congress, highlighted by Macomber, the Revenue Act of 1921, Koshland, the Revenue Act of 1936, the Strassburger and Sprouse cases, the Revenue Act of 1954 and the Tax Reform Act of 1969. The 1969 Act could be generally described as imposing taxation on all stock dividends except those involving the pure Macomber fact pattern. ${ }^{92}$ The 91 st Congress upheld the vitality of the election theory by reenacting it and passed other specific subsections to cope, by what could be described as a substance over form approach, with the more sophisticated techniques which had developed. The Treasury looks to the change in equity ownership as the test for the characterization of the stock dividend; hence, taxing a result rather than an actual receipt of a tangible item. Thus, section 305 has been transformed from a section generally granting exemption, to a section generally taxing, with the only exemptions being those of the Problem I type or those similar to Macomber. However, section 305 is not a congressional mandate for the overthrow of Macomber, rather, it specifically works within its framework so that a direct confrontation need not be expected.

As Problems III, IV and V demonstrate, section 305(c) is the source of power whereby the Treasury is authorized to treat disguised dividend transactions as constructive stock dividends. It is also true that a taxable constructive stock dividend can result from distribution of common on common if cash is paid to convertible debentures. Also, certain reorganizations and recapitalizations usually under the tax free nonrecognition rules, or a decreasing conversion ratio on a convertible preferred stock may be deemed to include a constructive stock dividend under section 305 (c). The power to constructively treat certain transactions poses a diversity of questions-primarily as to the precise scope, legality ${ }^{93}$ and propriety of the regulations regarding

92. It should be noted that Congress would have a better than even chance of overturning Eisner $v$. Macomber by enacting a specific tax on all stock dividends as a direct confrontation to that case. This is also true because the definition of income has greatly changed in the half century since that decision.

93. A study of the delegation by Congress of the section 305(c) powers will reveal the impotency of the improper-delegation-of-legislative-power argument. It has been stated that "the most effective metbod for expression of legislative intent well may be delegation, with virtually no standards, but with strong legislative influence upon policy creation after the delegation has been made." K. Davis, Administrative LAw TeXT 51 (1959). There are other examples of specific regulation-making power in the Internal Revenue Code: section 1502, which was first enacted as section 141(b) of the Revenue Act of $1928 \mathrm{ch} .852,45$ Stat. 791, 831; and section 385, enacted by the Tax Reform Act of 1969, Pub. L. No. 91-172, § 415(a), 83 Stat. 
such transactions. The increasing conversion ratio-Problem IIIperiodic redemption-Problem IV-and decreasing conversion ratio-Problem $\mathrm{V}$-involve a problem of ascertaining the meaning of realization of income as related to a "resulting" or constructive dividend.

The theory of section 305 taxation is that when a transaction has the effect of increasing the proportionate interest of a shareholder a realization has occurred yielding an ascertainable amount of income. In the more remote cases a taxpayer may receive nothing tangible and yet still be taxed. Section 305, as part of the personal income tax provisions, must conform with the requirements of the sixteenth amendment which permits the non-apportioned taxation of "incomes." ${ }^{94}$ The constructive distribution is in truth a realization of sorts of the stock dividend which is taxable as income and not within the general exemption Eisner v. Macomber grants to certain stock dividends. The crux of this issue revolves around the heart of the income tax itself-the definition of income. Every case concerned with realization, income, assignment of income, substance over form, business purpose and step transactions is directly or indirectly related to that issue. Certain of these cases are so related to each other that a court's discussion of one aspect-for example, realization-may also be a discussion of another-definition of income..$^{95}$

The definition of income has been greatly broadened over the years and the principle of realization has also undergone considerable change. What was really a conceptualized view of the realization of

487,613 . It seems that policy decision-making via regulation is coming into greater vogue ( $\$ 385$ and $\S 305(\mathrm{c})$ ), since it is the most appropriate means of dealing with a problem where a special expertise is nceded. Notc, Toward New Modes of Tax Decisionmaking-The DeblEquity Imbroglio and Dislocations in Tax Lawmaking Responsibility, 83 HARv. L. Rev. 1695 (1970). The vitality of the section 305(c) regulations is especially strong because a specific delegation is binding upon the courts as long as it is within the granted power, is properly issued, and is reasonable.

94. The taxation of corporations, Act of Aug. 5, 1909, ch. 6, § 38, 36 Stat. 11, 112, was held in Flint v. Stone Tracy Co., 220 U.S. 107 (1911), not to be a direct tax, but an excise or indirect tax upon the exercise of privilege of doing business in a corporate capacity.

95. The attorney of the taxpayer who believes he is being unjustly taxed by one of the more remote constructive dividends would of necessity have to review carefully the realization cases beginning with Eisner v. Macomber. See The Reorganization Cases, supra note 18; James v. United States, 366 U.S. 213 (1961); Comm'r v. P.G. Lake, Inc., 356 U.S. 260 (1958); Corn Prods. v. Comm'r, 350 U.S. 46 (1955); Arrowsmith v. Comm'r, 344 U.S. 6 (1952); Hort v. Comm'r, 313 U.S. 28 (1952); Harrison v. Schaffner, 312 U.S. 579 (1941); Helvering v. Eubank, 311 U.S. 122 (1940); Helvering v. Horst, 311 U.S. 112 (1940); Helvering v. Clifford, 309 U.S. 331 (1940); Blair v. Comm'r, 300 U.S. 5 (1937); Lucas v. Earl, 281 U.S. 111 (1930); Equitable Publishing Co. v. Comm'r, 356 F.2d 514 (3d Cir. 1966), affg George W. Knipe, 34 P-H Tax 
income has become one of appropriate timing or expediency of taxation. In truth, the gain or appreciation being a variation in status or an event occurring to the asset-the stock-rather than it being "received or drawn by the recipient . . . for his separate use, benefit and disposal," "96 is taxed by section 305 because of timing and policy. This has been decided by the legislators and administrative officials to be the proper moment for taxing the accretion or increase as realized income. As far as the taxing authorities are concerned, any variation or event is a sufficient condition for imposing a tax on the gain. However, the more remote or less significant the timing, the greater the opportunity for a taxpayer to convince a court to overrule the time selected, by describing the result as being in violation of the taxpayer's due process rights.

The Congress and Treasury may bolster their decision by arguing that the section 305 realization is needed to prevent tax evasion and to limit conglomerate growth. The Treasury could also argue from the realization, definition of income and assignment of income cases, and the substance over form, business purpose, and step transaction theories. In light of the Horst and James ${ }^{97}$ approach of the Supreme Court, a taxpayer would need to point to an inequity of significant magnitude to prevail on the due process argument and convince the Court to rule that no income was realized. The taxpayer's argument could be strengthened by questioning the gain or accretion itself, since a difficult valuation question may not substantiate the Treasury's position regarding the value of the increase. Problem V's decreasing conversion ratio is a prime example of this issue. Should the taxpayer

Ct. Mem. 731 (1965); Comm'r v. Ferrer, 304 F.2d 125 (2d Cir. 1962); Sparks Nuggett, Inc., 39 P-H Tax Ct. Mem. 359, 378 (1970).

For an in-depth study of assignment of income and realization, see Lyon \& Eustice, supra note 73, at 362; and Eustice, Contract Rights. Capital Gain. and Assignment of Income-the Ferrer Case, 20 TAX L. Rev. 1, 51 (1964). This is neither the time nor place to make such a comprehensive study. It should center on the definition used in Eisner v. Macomber which has evolved into more of a generalization.

"Derived - from - capital"; "the gain - derived - from - capital," etc. Here we have the essential matter: not a gain accruing to capital, not a growth or increment of value in the investment; but a gain, a profit, something of exchangeable value proceeding from the property, severed from the capital however invested or employed, and coming in, being "derived," that is, received or drawn by the recipient (the taxpayer) for his separate use, benefit and disposal; that is income derived from property. Nothing else answers the "description." 252 U.S. at 207 (emphasis in original).

96. 252 U.S. at 207 (emphasis by Court).

97. James v. United States, 366 U.S. 213 (I96I); Helvering v. Horst, 31 I U.S. I12 (I940). 
prevail, the Treasury may be forced to retreat to the more acceptable position of imposing taxation at the time of the stock's disposition.

The problems of realization are even more accutely encountered when preferred stock, usually convertible, is included in the fact pattern. Subsections $305(b)(3)$, (4) and (5) pertain to constructive or actual distributions on or of preferred stock. These provisions, especially section 305 (b)(3), were added by the Senate to clarify the House version which had made the distribution of section 306 stock a distribution of property and not stock for purposes of applying the disproportionate distribution rules of section $305(\mathrm{~b})(2)$. They were also necessary since the definition of "property" in section 317 expressly excludes stock of the distributing corporation. ${ }^{98}$

The increasing taxation of stock dividends by section 305 will reduce the use of and need for section 306 since less stock will be tax free and untainted as required by section 306. A distribution of nonconvertible preferred on common, the only class outstanding, is not within the scope of section 305 , but a typical example of what section 306 still covers. However, gain on section 306 stock is not recognized until disposition which may now make such stock desirable to taxpayers. The delay may provide the necessary time to discover a means of avoiding the taxable disposition of section 306 stock.

Section $305(b)(3)$ taxes as a section 301 distribution a dividend of stock which results in preferred stock being distributed to some stockholders and common stock being distributed to the other stockholders. All stock dividends on preferred constitute a section 301 distribution under section $305(b)(4)$, whether the distribution is actual or constructive and regardless of the requirement that the distribution have a disproportionate effect. A distribution of common or even preferred on preferred is clearly taxed by section $305(\mathrm{~b})(4)$.

Section 305(b)(4) provides the setting for one of the strongest cases to argue that a constructive dividend is non-taxable and a due process violation. If both common and convertible preferred stock are outstanding, the legislative history indicates that an annually increasing conversion ratio would be taxed. The conversion is into a larger number of shares. No cash dividends are or need be paid for this result to occur. There are two exceptions to section 305(b)(4). One allows tax free treatment of a stock dividend on preferred made solely to take into account a stock dividend or stock split on the stock into which

98. See H. R. REP. No. 413, at 113 , and $\S 305(b)(3)$ in particular. 
it was convertible. Second, an increasing redemption price-hence a greater than issue price-which is treated as constructively received will not be taxed during the period in which the stock cannot be called if it is a "reasonable call premium." 99

Section 305(b)(5) is the last exception in the section 305(b) series and imposes taxation, through section 301 , on any distribution of convertible preferred unless it is established to the Commissioner's satisfaction that it will not have a disproportionate result. If a substantially full conversion is likely, as in twenty years, no disproportionate distribution will result; however, a conversion period limited to four months would probably and readily permit an individual stockholder to increase his interest in the corporate assets and, therefore, taxation would be imposed. ${ }^{100}$

Section 305 raises a conflict between its provisions and those dealing with corporate organizations and reorganizations. The broad based legislative grant of regulation making power for constructive distributions can not only tax situations where "a 40 percent stockholder of a corporation receives a constructive dividend when the 60 percent stockholder causes the corporation to redeem 10 percent of its stock from him," 101 but, also, can find a taxable dividend applicable to the continuing shareholders in the case of a non-pro rata spinoff, ${ }^{102}$ or of an (A) type reorganization wherein some shareholders take stock and others take cash. ${ }^{103}$

There exist a number of additional conflicts between sections 305 and 368 for which no provision is made. ${ }^{104}$ This is especially true in

99. H.R. ReP. No. 413, at I15; S. REP. No. 552, at 154. The Treasury proposals had said 10 percent was a reasonable call premium. 1969 House Hearings 5198.

100. Section 305(d)(2) defines a shareholder to include a holder of rights or of convertible securities or debentures, and section 305 (d)(1) defines stock as including rights. Thus, a taxable dividend can result to a warrant holder if his equity interest increases because of a change in the warrant price. If the warrant is of preferred stock, section 305(b)(4) is applicable. If a convertible debenture is held which pays interest $(\S 305(\mathrm{~b})(2)(\mathrm{A})$ property), a related stock dividend of common on common (§305(b)(2)(B), even though a pure Eisner v. Macomber), could result in section 305(b)(2)'s taxation. See also the possible effect that section 305(d)(2) treatment of warrants and convertible debenture holders has upon section 356(a) treatment of such services as boot. BITTKER \& Eustice 9 I 14.34 .

101. A distribution which qualifies as a gift would not be within the section 305 rules. See S. REP. No. 552, at 154: "This provision ( $\$ 305$ ) is not intended to affect the characterization of a non-pro rata distribution (or deemed distribution) as a gift, compensation, adjustment of purchase price, and so forth. For example, a non-pro rata distribution on common stock may have the effect of a gift to the recipient by the other stockholders."

102. INT. REv. CODE OF 1954, §368(a)(1)(D) and/or § 355.

103. 1969 Senate Hearings pt. 6 , at 5154,5194 .

104. Cf. INt. Rev. CODE OF 1954, §§ $332 \& 346$. 
the reorganization area when a (B) acquisitive reorganization or an (E) recapitalization is involved. In a $(B)$ reorganization where the acquiring corporation issues a second class of stock, such as preferred, taxation will be imposed on the stockholders where the relative equity interest is disproportionately increased. ${ }^{105}$ In an (E) recapitalization, if the corporation issues additional preferred or common stock in exchange for dividend arrearages, under section 368 such a transaction qualifies as tax free; however, if the preferred stock dividend arrearages were satisfied through a distribution of preferred or common stock to the preferred shareholders the distribution is taxable under section $305(\mathrm{~b}){ }^{106}$ This in particular will have to be clarified to include distributions of all arrearages ${ }^{107}$ as taxable. ${ }^{108}$

105. Eustice, supra note 48 , at 547 . Eustice also discusses, at 545 , the problem of the "income" term whereby additional shares may be issued to the sellers if certain contingencies occur after the original distribution. The old regulations applicable to the old preference dividend exception provided for a five year escape rule. Treas. Reg. $\S 1.305-3(b)(4)$. The new section 305 proposed regulations do not clarify this by providing for a similar result in disproportionate distributions as part of a $\S 368$ (B) reorganization.

106. 1969 Senate Hearings pt. 6 , at $5154,5195$.

107. The recapitalization and arrearage issue also set the stage for one of the rare moments of Congressional dialogue concerning section 305 . The question was raised regarding the possible effects the stock dividend section might have where

... the older stockholders exchange some or all of their preferred stock for additional common and continue to be active in the business. This has been a classic type of recapitalization which has always been considered tax free in the past. Am 1 correct in that there is no intention to change this type of bona fide business purpose? (Mr. Aiken)

Mr. Long. The Senator is correct. There is no intention to impose a tax on a bona fide recapitalization of this type, except to the extent stock is given in payment for dividend arrearages on the preferred stock. 115 CONG. REC. 37,902 (1969).

Note that a taxpayer will also desire to fall indirectly within section 301 through sections 368 and 356 , sinee the amount treated as dividend is different than if it were directly through section 305 . In section 356 there is the special rule of section $356(a)$ (2) of a dividend within a gain approach, whereby dividend income is reported only if and to the extent of the recognized gain (boot), the remainder is treated as gain from the exchange of property.

108. On the administrative front, the possible application of one of the more remote constructive distribution problems will pose the additional difficulty to the Treasury of finding those unintentional non-declarers of section 305 taxable income. Such relatively small amounts will probably slip by the statute of limitations provision of section 6501 of the 1954 Code. In those cases where the 6-year period is pressed by the Service, it would be interesting to discover what would be "a manner adequate to apprise" the Treasury, as section $6501(\mathrm{e})(1)(\mathrm{A})(\mathrm{ii})$ requires, when the stock is for other reasons listed on the return. An allowance for a loss would bolster a Treasury argument that such a distantly-reeeived realization was proper.

The transition rules for stock dividends are delineated in section 421(b) of the Tax Reform Aet and Proposed Treas. Reg. $\S 1.305-8,36$ Fed. Reg. 5226 (1971). Generally, the new rules apply to all distributions actually or constructively made after January 10, 1969, in tax years ending after that date. Detailed and highly complicated rules deferring application (sometimes 


\section{The Proposed Regulations}

The proposed regulations ${ }^{109}$ are the means whereby the Treasury explicates the statute and to a general extent clarifies the treatment of particular transactions. Generally speaking, the transactions included were those the Commissioner was logically and specifically empowered to embrace. The following review and examination of the Regulations will concern itself with the more general answers, examples and problems proposed by the Regulations and secondly, will analyze the new relationship between section 305 and corporate reorganizations.

\section{Part I}

The Regulations, following the growth of the statute, have undergone a metamorphosis all their own. The number of examples has jumped from the eight in the 1969 Regulations to twenty-eight with an equally impressive growth in supporting statements and explanations. Section 305 and the field of stock dividends appears to have left behind all traces of adolescence and entered maturity.

Preferred Stock Defined. A more comprehensive and reaffirmed definition of preferred stock was needed in view of the numerous and intricate roles preferred is called upon to play. The Regulations define preferred stock as including "stock the terms of which require, in all events, periodic distributions with respect to it of stock or rights to acquire stock, provided the corporation has another class of stock outstanding." 110 This definition is only a more pointed restatement of the old regulations. ${ }^{111}$ The Regulations specifically apply this definition to a class of stock which requires an annual distribution to be made on it and to a class which may be converted and the conversion ratio is annually increased. ${ }^{112}$

The application and use of what is more usually termed preferred

until January 1, 1991) of section 305 are provided in the remainder of section 421 (b), especially section 421 (b)(2). They permit tax free distributions where stock is outstanding or issued pursuant to a contract binding on or before January 10, 1969. In cases where T.D. 6990, 1969-1 CUM. BUL.. 95 (promulgated January 10, 1969) would not have applied, April 22, 1969 will be substituted for the January 10, 1969 date. As an example, Problem IV's periodic redemption plan would come within the April 22, 1969 date since it was not within the scope of T.D. 6990 .

109. Proposed Treas. Reg. $\S \S 1.305,1.305-2,1.305-3,1.305-4,1.305-5,1.305-6,1.305-7$ \& 1.305-8, 36 Fed. Rcg. 5221-27 (1971).

110. Id. $\S 1.305-5(\mathrm{a})$.

111. Treas. Reg. § 1.305-3(b)(1) (1969).

112. Proposed Trcas. Reg. \& 1.305-5(c), Ex. 1, 36 Fed. Reg. 5225 (1971). 
stock, preferred as to cash dividends, throughout the Regulations has engrained the meaning even further. However, this should not limit the definition since there may be other rights affecting stock. The definition of common stock is thus simply all stock which is not preferred.

Fractional Shares. There is no true de minimus ${ }^{113}$ exception with respect to disproportionate distributions in section 305 . However, the Regulations allow cash distributions in lieu of fractional shares provided the purpose of the cash distribution is to save the corporation trouble, expense and inconvenience and not to give any particular group of shareholders an increase in proportionate interest. For the purpose of fractional shares, if the total amount of cash distributed does not exceed five percent of the total fair market value of the stock distributed, then the amount shall be considered to be for the above stated valid purpose. ${ }^{114}$ Cash is to be treated as redemption proceeds and characterized by section $302 .{ }^{115}$

"Series," "Result of" and "Nexus". The Regulations have lumped the treatment and analysis of these factors under the broad heading of "Disproportionate distributions." 116 The Treasury proposals take the same persistent and forceful approach as subsection 305(b)(2), but with very little indication of those factual transactions which are not to be encompassed by $305(\mathrm{~b})(2)$. The main thrust of the Regulations is on the result of the distributions and not the mens rea of the corporation. There is no requirement for a plan, specific or otherwise. Thus, the Regulations include cash distributions which are not part of an overall plan but "are independent and unrelated"- -such as quarterly stock dividends. ${ }^{117}$ Also, the cash or property acquired may be acquired by other than the corporation's distribution, as when a section 304 related corporation purchases part of the stock dividend from those shareholders who desire cash. ${ }^{118}$ While the

113. S. REP. No. 552, at 154.

114. Proposed Treas. Reg. § 1.305-3(c)(1), 36 Fed. Reg. 5225 (1971).

115. Id. See also Gordon A. Erickson, 56 T.C. No. 84 (1971).

116. Proposed Treas. Reg. \& I.305-3, 36 Fed. Reg. 5222 (I97I).

117. $I d$. $\S 1.305-3(\mathrm{~b})(2)$.

118. Id. $\S 1.305-3(b)(3)$. The use by the Treasury in Proposed Reg. $\S 1.305-3(c)(3)$ of a related corporation as the improper source of the eash element was within the intended powers of the Congressional mandate. Whether the Treasury can continue to so eonsolidate transactions or separate them into step transactions will depend upon the circumstances of each case. It seems certain that this cannot be done whenever the Treasury would like to impose taxation at its choosing. 
Treasury has properly included these transactions within the Regulations, it has not expounded upon what transactions similar to those described might evoke a different conclusion-such as redemption situations, ${ }^{119}$ (E) recapitalizations ${ }^{120}$ or distribution and redemption more than four years apart. ${ }^{121}$

The Treasury, slow to give any ground in this area after many years of doing battle on the short side, is reluctant to reveal any of the limitations of its new legislative weapon. There is a distinct need though, for the Treasury to provide more informative generalizations as to the intention of the statute and thus give greater guidance toward the resolution of cases not specifically covered by the text or examples. The short and restrictive wording of the Proposed Regulations ${ }^{122}$ conveys a sense of strict liability which is not the case. Actually the two elements of subsection 305 (b)(2) must be in conjunction or have an intended relationship.

The twelve month standard originally used by the Treasury has been changed to a longer thirty-six month ${ }^{123}$ rule and presumption. Only those distributions more than thirty-six months apart will be presumed not to result in violation of subsection 305(b)(2), ${ }^{124}$ and this is upon the condition that the two elements are not made pursuant to a "plan." 125 No further explanation of a "plan" is given. The full effect of the thirty-six month presumption cannot be immediately appraised but will greatly depend upon those transactions which possess remotely connected elements and are within the presumption. Thus, assume a factual setting with the necessary elements separated by thirty-five months, a weakly related linkage and gross inequity from imposing taxation. Such a case, if pressed by the Treasury, could be the basis for a series of restrictive decisions.

Adjustments in Conversion Ratio. The Regulations ${ }^{126}$ permit cer-

119. Proposed Treas. Reg. $\$ \S 1.305-3($ e), Exs. $10 \& 11,1.305-5$ (c), Exs. $8 \& 9,36$ Fed. Reg. 5223-25 (1971).

120. Id. $\S 1.305-3(\mathrm{e})$, Ex. 12.

121. Id. Ex. 11.

122. As exemplified in id. $\S 1.305-3(b)(3)$.

123. The probable reason for the longer 36 month criteria is to permit the lnternal Revenue Service more leeway in its determinations and restrain the corporations as a whole.

124. The examples used by the Regulations do not specify with particularity the dates the two elements span as the Treasury proposals did with their six-month nexus. See Proposed Treas. Reg. § 1.305-3(e), Ex. 7, 36 Fed. Reg. 5223 (1971).

125. Id. $\S 1.305 .-3(\mathrm{~b})(4)$.

126. $I d . \S 1.305-3(\mathrm{~d})$, Ex. 7. 
tain "adjustments" with regard to the conversion ratio of convertible stock or securities. Thus, a stock dividend made with respect to the stock into which the convertible stock may be converted will not increase the proportionate interests, provided that an adjustment in the conversion ratio reflecting such stock dividend is made within three years and before the aggregate stock dividends total at least three percent of the stock outstanding. ${ }^{127}$ This Regulation, while a strict and formal procedure, is a way to avoid dividend treatment and provides a limited de minimus rule. As presently written it will be a partial means of shielding belatedly discovered minor unintentional taxable situations in spite of its relatively strict procedural criteria.

Proportionate Interests. The true meaning of "proportionate interests" has been left to the Problems and the cases already discussed. Section 305(c) authorizes the Treasury to treat, for the purposes of sections 305 and 301 , certain transactions as if they were distributions with respect to any shareholder having an increase in the proportionate interest in earnings and profits or assets. The Regulations under this section have no specific mention of the meaning of an increase in proportionate interests, but refer to the examples throughout the Regulations. Section 305(c) only treats and characterizes certain transactions as deemed distributions which must then comply with the provisions of subsection (b).

Examples of subsection $305(b)(l)$. The Regulations are of little practical value since the election provision of the old statute is merely restated. The Regulations do not reach beyond their immediate sphere and the examples ${ }^{128}$ impose taxation only where the active choice exists.

Examples of subsection 305(b)(2). Almost half of the examples found in the Regulations are in the provisions which amplify disproportionate distributions. ${ }^{129}$ Most of the examples are concerned with the more simple transactions which do or do not increase the proportionate interest in the equity, ${ }^{130}$ increase conversion ratios, ${ }^{131}$ decrease

127. Id. $\S 1.305-3(\mathrm{~d})(1)$. The distributing corporation in the year of the distribution must also provide a statement of election by the corporation and a copy of the corporate authority for such an adjustment procedure. $I d$. $\S 1.305-3(\mathrm{~d})(2)$.

128. Id. § 1.305-2(a), Exs. $1 \& 2$.

129. Id. \$ 1.305-3(e), Exs. 1-13.

130. Id. $\S 1.305-3(\mathrm{e})$, Exs. 1-3. Ex. 1 is a restatement of Problem II of this article and Ex. 2 is a restatement of Problem $I$ of this article.

131. Id. $\S 1.305-3(\mathrm{e})$, Ex. 6 . 
conversion ratios, ${ }^{132}$ as well as with plans or programs of periodic redemption. ${ }^{133}$

The remaining examples of the coverage of this subsection describe situations which fall outside the taxing scope of section 305 as alluded to by the Treasury, the Congress and the Committee Reports. In a single and isolated partial redemption of a seventy percent shareholder's stock, the other shareholder owning thirty percent is not treated as constructively receiving a distribution to which section 301 applies. ${ }^{134}$ Also, where a corporation, in preparation for the retirement of a number of its larger shareholder officers, redeems a nominal amount of stock from each shareholder officer, and the redemption is not part of a periodic plan, the remaining shareholders are not treated as receiving a taxable distribution even though their proportionate interests in the equity have increased. ${ }^{135} \mathrm{Or}$, if in a single and isolated transaction in preparation for the retirement of the major shareholders, the old common is exchanged for preferred and new common as part of the recapitalization, the exchanges are not within the intended purview of section $305 .{ }^{136}$

By far, the most interesting and challengeable fact pattern is Example 13 of the Regulations. ${ }^{137}$ Example 13 presents a fact pattern where Corporation $\mathrm{V}$ is organized with two classes of stock, class $\mathrm{A}$ common and class B convertible preferred. The preferred stock is issued for $\$ 1.00$ per share convertible at a fixed ratio, not subject to an antidilution adjustment, and is redeemable in 10 years for $\$ 200$ per share. During the year, a stock dividend of class A common is distributed on the outstanding class A common. The Treasury, attempting to determine the status of the stock dividend on the class A common, concludes that the actual stock dividend increases the proportionate interests of the class A stockhoIders, and that the class B stockhoIders

132. Id. $\S 1.305-3(\mathrm{e})$, Ex. 7.

133. Id. $\S 1.305-3(\mathrm{e})$, Exs. $8 \& 9$. Note that there is no further clarification of the Treasury proposals which described the plan as "Board of Directors" authorized.

134. Id. $\S 1.305-3(\mathrm{e})$, Ex. 10. Note that none of the factors which might more clearly describe an "isolated" transaction are revealed. It appears that only a transaction possessing what the Treasury believes is a strong non-dividend purpose will be held to be isolated.

135. Id. $\S 1.305-3(\mathrm{e})$, Ex. 11. This is also a prime example where the two elements do not have the necessary relationship or nexus.

136. Id. $\S 1.305-3(\mathrm{e})$, Ex. 12. This last transaction is what Senator Aiken described as the "classic" recapitalization and is specifically not included as a taxable increase in the Regulations. See note 107 supra.

137. Proposed Treas. Reg. $\S 1.305-3($ e), Ex. 13, 36 Fed. Reg. 5223 (1971). The reference in Ex. 13 should be to Ex. 8 and not Ex. 6 of the Prop. Reg. $\S 1.305-5$ (c). 
constructively receive property, thereby causing the stock dividend to be taxed under section 301 . The distribution of property to the class B preferred shareholders occurs through the constructive distribution rules of section 305(c) and subsection 305(b)(4). The excess redemption price over the issue price is deemed to be a substitute for dividends, assuming there are no facts to show that the excess constitutes a reasonable call premium, and these constructive dividends are considered to be distributed ratably over the 10 year period.

The original reason motivating Congress to strengthen section 305 was for the purpose of effectively dealing with the situations where cash dividends were paid to some shareholders while others were given corresponding increases in their proportionate interests, and where preferred stockholders received the equivalent of dividends on preferred stock which were not taxable under the prior provisions of section $305 .{ }^{138}$ The examples cited by the Senate Committee on Finance were increasing and decreasing conversion ratios on preferred stock, periodic redemption plans and excess redemption prices on preferred stock ${ }^{139}$ - the Treasury proposals before Congress utilized increasing and decreasing conversion ratios on preferred stock as the passive transactions exemplifying the sought after situations. ${ }^{140}$ Thus, the constructive distribution in all these transactions was described as the stock which increased the proportionate interests, and not as the receipt of property.

Example 13 is not concerned with the constructive increase in proportionate interests. The result is an actual increase since the preferred stock is convertible. The convertibility factor is a necessary condition to the resulting increase in the proportionate interests, otherwise the transaction would be a Problem I transaction where no taxation results even with actual cash distributions to the non-convertible preferred.

Subsection 305(b)(2) requires two connected distributions, one a stock dividend, whether actual or constructive, and the other of property. For the purposes of section 305, "property" is defined as "money, securities, and any other property; except that such term does not include stock in the corporation making the distribution (or rights to acquire such stock)." 141 The only means by which the Treasury could

\footnotetext{
138. See S. ReP. No. 552, at 151 ("General reasons for change”).

139. Id. at 153-54.

140. See 1969 House Hearings 5195-98.

141. INT. REv. CODE OF 1954, § 317(a).
} 
reach the transaction described in Example 13 was by utilizing the provisions of $305(\mathrm{~b})(4)$ and 305 (c) to find that the preferred B shareholders receive a taxable constructive distribution of property. Section 305(b) states that this "distribution shall be treated as a distribution of property to which section 301 applies." 142 The fact remains that as per subsection 305(b)(2), the final result was an increase in the proportionate interests of the class A shareholders and the class B shareholders, holding convertible preferred stock, received property, notwithstanding the fact that the property was constructively received under another subsection of section 305. ${ }^{143}$

The argument against the propriety of Example 13 is concerned with the use by subsection $305(\mathrm{~b})(2)$ of the $305(\mathrm{~b})(4)$ constructive distributions as the creator of the "distribution of property." The argument is based on the lack of specific statutory authorization for such use, the lack of general or specific intent by Congress, ${ }^{144}$ and the excessive use of the step transaction or substance over form approach. Also, it can be argued that Example 13 is a prime example of the passive, non-participating constructive receipt of income which is not existing, and therefore not taxable because it is not truly "realized."

The fact that the statute does not specifically describe such a use by subsection $305(\mathrm{~b})(2)$ does not exclude the use of the Example 13 technique. The wording of section 305 includes and defines the "property" for subsection 305(b)(2)(A) as the constructive "distribution" of sections 305(c) and 305(b), thereby including all subsections of section 305(b). Further support is found in the broad grant that section 305(c) gives the Treasury to promulgate constructive distribution regulations. The Senate Committee on Finance stated that the general reasons for the provision were that the 1969 regulations did "not cover all the arrangements . . . where cash dividends can be paid to

142. Id. §305(b).

143. Example 4 of the section 305(b)(2) Regulations could be viewed as the Treasury's taxing a simple distribution on simple common stock. In Example 4, a corporation makes a distribution of rights to common stockholders to acquire common stock of the same class and taxes this distribution if there are either outstanding convertible securities or preferred stock which do not provide for an adjustment in the conversion ratio to reflect the distribution. However, the approach taken by the Treasury to support its conclusion is the treatment of the convertible securities or the preferred stock as if they were outstanding stock. Therefore, using the same logic as Example 13, the stock distribution is one which is held to increase the proportionate interests of the common shareholders.

144. Since the Treasury proposals and Committee Reports did not present the same facts as Example 13, it may be argued that it was never intended by Congress to include such a transaction. 
some shareholders and other shareholders can be given corresponding increases in proportionate interest." 145 The alteration of a shareholder's interest through a tax-free stock dividend provision was the transaction and inequity Congress intended to prohibit. A strict view of the statute or its rationale would conflict with the general intent of the lawmakers, especially since forms of such phantom or passive transactions were part of the Treasury proposals and the Committee Reports. Also, the substance over form approach is part of the general intent Congress had in enacting the statute to tax such escape arrangements. The Treasury proposals and Committee Reports did not present the same fact pattern as Example 13 but it is believed that the earlier stated reasons supporting the validity of Example 13 will generally prevail.

Examples of subsection $305(b)(3)$. The Regulations prescribed for subsection 305(b)(3) have two examples, the first of which is simple and directly on point while the second is more complex. ${ }^{146}$ The second example presents a fact situation in which a corporation having only one class of $\mathrm{A}$ common declares a dividend payable in newly authorized class B preferred which is convertible into class A stock no later than 6 months from the date of distribution, at a price only slightly higher than the fair market value of the class A stock on the date of the distribution. The distribution is determined to result in the taxable receipt of preferred stock by some common shareholders and common stock by other common shareholders. The Treasury utilizes the same factors as those in the subsection $305(\mathrm{~b})(5)$ Regulations $^{\mathbf{1 4 7}}$ to "reasonabl[y] anticipate" that within a relatively short period of time some shareholders will exercise their conversion rights and some will not. ${ }^{148}$ The Treasury seems to be demonstrating that it will not be strictly confined to one particular subsection, for example 305(b)(5), as its means of reaching a particular transaction, and, depending upon the circumstances, may use a stronger or more versatile subsection. However, the uncertainties created for the tax practitioner are that much greater.

Subsection $305(b)(4)$. Almost one third of all the section 305 Regulations are within the subsection $305(\mathrm{~b})(4)$ Regulations. ${ }^{149}$ The most

145. S. ReP. No. 552, at 151 .

146. Proposed Treas. Reg. \& 1.305-4(b), Exs. 1 \& 2, 36 Fed. Reg. $5224-25$ (1971).

147. Id. $\S 1.305-6(\mathrm{a})(2)$. Note the similar approach taken by the Treasury in Ex. 2 of Proposed Treas. Reg. $\S 1.305-6(\mathrm{~b})$.

148. Proposed Treas. Reg. $\S$ 1.305-4(b), Ex. 2, 36 Fed. Reg. 5224-25 (1971).

149. Id. \& 1.305-5. 
important factor of subsection $305(b)(4)$ is that the distribution need only be made on or with respect to preferred stock. An exception is made for those distributions which are made to avoid the dilution of a conversion right. ${ }^{150}$ The requirement of any connection, or necessity of a second distribution of property is excluded.

A redemption premium will be taxed, since it will be considered under section 305(c) to be a distribution of additional stock constructively received by the preferred stock over the period during which the stock cannot be called. As the Treasury proposals first indicated, however, a reasonable call premium will not be taxed. The Regulations define reasonable as a redemption premium not exceeding ten percent of the issue price on stock which cannot be redeemed for at least five years. ${ }^{151}$ It must be noted, though, that the Regulations also describe examples of taxing the entire excess redemption value ${ }^{152}$ or taxing only the value which exceeds a reasonable call premium. ${ }^{153}$

Subsection $305(b)(5)$. The twenty year and four month time periods used by the Committee Reports are restated in the two fact patterns exemplifying subsection $305(\mathrm{~b})(5){ }^{154}$ A normally taxable distribution of convertible preferred will not be taxable if the corporation establishes that it will not result in a disproportionate distribution. Two somewhat dependent conditions need exist for a disproportionate distribution to result. ${ }^{155}$ First, it must be required that the conversion right be exercised within a relatively short period of time after the stock distribution and secondly, taking into account the other factors of the distributed stock-dividend rate, redemption provisions, marketability of the stock, and conversion price-it must be "anticipated" that some shareholders will exercise their conversion rights and some will not.

While the power of the statute and the strength of the Regulations is clear, the Regulations have not made any new clarifications except for listing the criteria or factors which will be considered in determin-

150. It is argued by some authors that the anti-dilution protection of the Regulations be interpreted or enlarged in scope so as to include various forms of commercially-bargained transactions. Committee on Corporate Taxation, New York State Bar Association Tax Section, Conments on Proposed Regulations Under Section 305 of the Internal Revenue Code of 1954 , as Amended by Sec. 42 l of the Tax Reform Act of 1969, 49 TAXES 460 (1971).

151. Proposed Treas. Reg. $\$ 1.305-5(c)$, Exs. 7-9, 36 Fed. Reg. 5221 (1971).

152. Id. \$ 1.305-3(e), Ex. 13.

153. Id. $\S 1.305-5(\mathrm{c})$, Ex. 8.

154. Id. $\S 1.305-6(\mathrm{~b})$, Exs. 1-2.

155. Id. § 1.305-6(a)(2). 
ing the likelihood of a disproportionate distribution. The scope of inclusion by any further objective standard has not been refined resulting in no great enlightenment to the reader. There is also the fact that the convertible redeemable preferred stock of the four month transaction (Example 2), is almost the same as the transaction taxed in Example 2 of the Regulations to subsection 305(b)(3).

Constructive Distributions. The Regulations of section 305(c) ${ }^{156}$ are somewhat abbreviated because of the fact that the transactions with constructive distributions were discussed throughout the Regulations of section 305(b). Yet, there was no real consistency in the previous examples as to when and why a deemed distribution existed. This particular part of the Regulations would have been an excellent place to make general clarifying remarks and especially negate the possibility that the same constructive distribution cannot do "double duty" by being both property to some shareholders and increase the proportionate interest of others.

Convertible Securities and Stock Rights. The Regulations ${ }^{157}$ and the Treasury proposals ${ }^{158}$ under subsection $305(\mathrm{~d})(1)$ and (2), treat stock rights and convertible securities as outstanding stock of the corporation for the purposes of subsection 305(b)(2) and a disproportionate distribution. Each class of stock is to be considered separately in determining whether an increase in the proportionate interest has occurred. ${ }^{159}$ The effect of this is an additional weapon in the arsenal to tax the varied increases that result from the increase of the ratio at which any debenture is convertible into stock, or from the increasing amount of stock purchasable under a warrant where the increase is related to a taxable distribution.

The Regulations, however, have not clarified this particular area. Although convertible debentures may result in taxation falling upon the holder, a more logical result is to trigger taxation on stock dividends paid to common shareholders. This same conclusion would hold true with distributions of cash and/or stock to stock warrants. Also, under subsection 305(d)(1) and (2) a warrant holder is treated as a shareholder and changes in such equity would be taxable; however, the right to acquire preferred stock would expose the warrant holder to the less stringent tests of taxation under subsection

156. Id. § 1.305-7.

157. Id. § $1.305-3(\mathrm{~b})(5)$.

158. 1969 House Hearings 5196.

159. Proposed Treas. Reg. § 1.305-3(b)(6), 36 Fed. Reg. 5223 (1971). 
305(b)(4). The Regulations have failed to enlarge on or enlighten the above possibilities.

Valuation. Under most of the subsections of $305(\mathrm{~b})$ the amount taxed is the fair market value of the distribution. When there is a section 305(c) constructive distribution, the value is the increase in the proportionate interest measured by the fair market value of the number of shares which would have been required prior to the transaction to give the shareholder the same equity ownership he has following the transaction.

There should be some difficulty accepting the Treasury's valuation of the dividend, especially with regard to nonredeeming shareholders. The cause of defective valuation may arise out of the attempt by the Treasury to view the increase in the proportionate interest in the aggregate. ${ }^{160}$ Also, the general approach the Treasury has utilized to determine what should be the taxable amounts is subject to criticism. ${ }^{161}$

\section{Part II}

Recapitalizations. The (E) recapitalization has its prime example where common stock is exchanged for preferred and new common. The theory behind not taxing such a transaction is the general intent of Congress to permit the subsection 368(a)(1) nonrecognition, provided that the transaction is isolated and not with the main purpose of avoiding taxation. The Regulations interpreting subsection $305(b)(4)^{162}$ use four examples of (E) recapitalization transactions whereby dividend arrearages are eliminated. The arrearages in these examples do not violate the provisions of section 305 (b) as long as the recapitalization is isolated and not used to increase the proportionate interest of one group of shareholders in relation to another. Yet, the arrearage related transactions are not as easily disposable as the Treasury has seemingly inferred. The separation and treatment, as section 301 dividend income, of accumulated arrearages and its relationship to redemptions is unclear. ${ }^{163}$

160. Tierney, Proposed Regs. Under 305(c) May Create Unexpected Taxable Stock Dividends, $35 \mathrm{~J}$. TAXation 187-88 (1971).

161. New York State Bar Association Tax Section, supra note 151, at 467-70.

162. Proposed Treas. Reg. § 1.305-5(c), Exs. 3-6, 36 Fed. Reg. 5225 (1971).

163. See New York State Bar Association Tax Section, supra note 151, at 487-88. See also Cummins Diesel Sales Corp. v. United States, 323 F. Supp. 1114 (S.D. Ind. 1971), where a taxpayer corporation redeemed another corporation's stock and pressed for a finding of nonconformity to the normally favored capital gain "exchange" status permitted by section 302 . This 
The exchange of preferred and new common for common is an example of what is more commonly known as the Dean-Hartzell ${ }^{104}$ recapitalization and is the starting point in the Regulations for recapitalizations of close corporations. ${ }^{165}$ Although the recapitalization may be free of section 305 taxation, any securities issued, such as the preferred stock, with a call premium would create future questions under the "reasonable" call premium standards of section 305. This results from the requirement that the security remain uncallable for at least five years to be classified as a security. ${ }^{166}$ The above is of special relevance to a close corporation, as is the absence of a workable means of determining the value of the issue price in a close corporation. ${ }^{167} \mathrm{~A}$ greater reliance on section 306 treatment for such transactions would alleviate much of the inherent uncertainty, especially those pertaining to a close corporation. ${ }^{168}$

Reorganizations Generally. The 1969 Regulations to the old section 305 had specific examples of the (B) type reorganization in their explanation of the old election by the shareholders as to the medium of payment. ${ }^{169}$ The only specific reference to a (B) reorganization by the new Regulations is within the initial general discussion of stock dividends where a (B) reorganization transaction is used to exemplify an increase in the conversion ratio or redemption which represents an "adjustment . . . not within the purview of section 305 because it is not a distribution with respect to its stock." 170 Adjustments of this

was because it wished to avail itself of the $85 \%$ dividend deduction of section 243 for the unpaid accumulated dividends. The court held that these accumulated dividends, paid to the corporation as holder of the preferred stock at the time it was called for redemption, were an indivisable part of the total sum paid on redemption, and part of the "exchange" transaction. Thus the taxpayer was forced to take the usually-desired capital gains treatment on the entire procecds, and was thus denied the section 243 deduction.

164. Dean, 10 T.C. 19 (1948); Hartzell, 40 B.T.A. 492 (1939).

165. For whatever the significance, it should be noted that (b)(5) and not the (b)(3) Regulations deal with this issue.

166. See BITTKER \& EUSTICE $\{$ i $4.01-.07,12.10-.11$.

167. See New York State Bar Association Tax Section, supra note 151, at 489. Note the approach taken by the Treasury with regard to stock options and its interpretation of an ascertainable fair market value. Treas. Reg. $\S \S 1.421-6 \& 1.421-6(\mathrm{c})$.

168. A close corporation could effectively postpone immediate income treatment to the distributee shareholder if it made annual distributions of nonvoting preferred stock to its common shareholders which qualified as section 306 stock. The section 301 treatment of such stock could be shifted to a lower tax bracket by gift. This would thus serve as a useful estate planning tool.

169. Treas. Reg. $\S 1.305-2(b)(2)$, Exs. $3-4$ (1969), exemplifying the increasing and decreasing conversion ratios within a (B) reorganization.

170. Proposed Treas. Reg. $\S 1.305-1(\mathrm{c}), 36$ Fed. Reg. 5221 (1971). 
nature previously had been excepted from the taxation imposed on preference dividends if they were to take into account a stock split or stock dividend, or the three year test ${ }^{171}$ or adjustments for consideration occurring within five years. ${ }^{172}$

The practical effect of the new Regulations is to isolate and permit such adjustments which are not with respect to the stock. Yet, the Regulations' explanation uses a time period of three years without clearly stating that the old five year objective test is rescinded. Specific examples would be in order clarifying what the time limit might be. These examples should state what factors would affect such transactions, and explain in detail the more relevant and practical reorganizations which are not to be included within section 305 taxation. This would not only relieve the tax attorney and his clients from unwarranted anguish, but would also permit the Code as a whole to be viewed in its intended form and purpose. ${ }^{173}$

\section{CONCLUSION}

As the history of stock dividends has revealed, the problems surrounding this area of the tax law have been revitalized and broadened, and a clear picture will take time to develop. Should the Treasury suddenly press forward within the strict letter of the law, it will be faced with constitutional issues pivoting on the very heart of the income tax itself. If the powers granted are judiciously used and taxation imposed with reasonable equity, the Treasury should remain in control of its grant. The 9 lst Congress believed its new section 305

171. Treas. Reg. $\$ 1.305-3(b)(3)$ (1969).

172. Id. $\$ 1.305-3(\mathrm{~b})(4)$.

173. Revised Notice to the Proposed Regulations: The "revised notice" to the section 305 Regulations is the Treasury's interim step to redefine and further clarify the original proposals of March 18, 1971. The notice generaliy affects only the transitional ruies or effective dates and the anti-dilution provisions. According to the Legislation and Regulations Division of the Treasury the "revised notice" has been drafted, reviewed, and is ready for imminent publication.

The transition dates will be modified and will thereby become effective at different dates for certain situations. In general these changes should be more favorable to the taxpayer.

The anti-dilution changes provide for greater explanation of this provision, especially in relation to convertible securities and the Regulations interpretation of subsections $305(\mathrm{~b})(2)$, disproportionate distributions, and (b)(4) distributions on preferred stock. The promulgation of additional affecting factors and further new examples were required and sorely needed.

The Reguiations as finaiized seem to be the last chance the Treasury will have to present its own interpretation and guidelines concerning the conflict and interplay of stock dividends visa-vis reorganizations and recapitalizations. The Legislation and Regulations Division of the Treasury indicated that these particular issues would be covered in the Final Regulations. 
to be the most effective means of handling the stock dividends field because of the intricate fact patterns within the expertise of the Service.

Although there has been no clear challenge by Congress to overrule Eisner v. Macomber, the practical effect of section 305 is much the same. The statute and budgetary need of 1936 were more conducive to rejection of the Eisner v. Macomber doctrine than the 1969 statutory history. Further support for the vitality of section 305 is found in the increasing trend of the Supreme Court to uphold a taxation as long as its result is not only sound in logic, purpose and intent, but, with all factors being considered, equitable. ${ }^{174}$

The cases have successively upheld as taxable income varying forms of accretion to value, whether it be the Horst type of 1940 or the James type of .1961. A 1965 Tax Court decision, George W. Knipe, ${ }^{175}$ affirmed by the third circuit continues the theory of imposing taxation when the time is most practical. The Tax Court more recently cited the Knipe case in Sparks Nugget, Inc., ${ }^{176}$ a 1970 decision.

In Knipe, the Tax Court found that the distributions made by one corporation $(X)$ to another $(Y)$ were in reality constructive dividends taxable to the two individual owners of corporation $\mathrm{Y}, \mathrm{A}$ and $\mathrm{B}$, each of whom owned fifty percent of $Y$ and jointly and equally owned eighty-five percent of $X$. The Tax Court said the payments did not represent real and genuine transactions entered into for profit or other business purpose. The initial distribution to corporation $Y$ was a guise and should not obviate the result that would have followed if distribution had first been made directly to A and B. The court then cited Helvering $v$. Horst and compared the power to dispose of the income by $\mathrm{A}$ and $\mathrm{B}$ with Horst. The power was the equivalent of ownership,

174. The following are excerpts of what the Supreme Court has said in this regard:

But taxation is not so much concerned with the refinements of title as it is with actual command over the property taxed-the actual benefit for which the tax is paid. . . . The income that is subject to a man's unfettered command and that he is free to enjoy at his option may be taxed to him as his income, whether he sees fit to enjoy it or not. Corliss v. Bowers, 281 U.S. 376, 378 (1930) (income from revocable trust).

[A gain] constitutes taxable income when its recipient has such control over it that, as a practical matter, he derives readily realizable economic value from it. Rutkin v. United States, 343 U.S. 130, 137 (1952) (extortion income).

175. 34 P-H Tax Ct. Mem. 731 (1965), affd sub nom., Equitable Publishing Co. v. Comm'r, 356 F.2d 514 (3d Cir. 1966).

176. 39 P-H Tax Ct. Mem. 359 (1970). 
and the exercise of that power to procure the income and earnings and profits to corporation $\mathrm{Y}$ being the enjoyment and hence the realization of the income.

In Sparks Nugget, excessive rents were held to be constructive dividends to the owner of letting and leasing corporations. Although the owner never directly received rent payments, the transfer from one wholly owned corporation to another was deemed a taxable event.

The general trend in many tax cases has been to look with more concern at the realities of the situation. The reasons supporting the taxation of these transactions may be labeled step transaction or substance over form, but the courts' logic and intended result are the same. Some taxpayers, especially at first, will suffer from such a strict approach. But, generally speaking, most transactions with bona fide intent not motivated solely by the aim of converting ordinary income treatment to capital gains treatment should be safe.

The issues and problems involved under section 305 are huge in scope and the Regulations have not only neglected to clarify existing questions but in some cases have only enlarged upon already existing problems-for example, the nexus and thirty-six month presumption, the subsection 305(b)(3) and (b)(5) overlap of authority, the method utilized for computing valuation, the lack of useful generalizations and the interplay with the reorganization sections.

The Regulations, while not precise or extremely helpful, are workable. For the most part the Treasury has generally had inadequate authority and power since the predecessors to new section 305 were enacted in 1921. The Treasury, almost subconsciously, has no desire to amplify the more intricate situations because of the fear that any or all favorable exceptions it reveals may be used against it. Now that the Treasury has the authority and mandate from Congress it will probably be a slow and difficult process for the taxpayers to discern what is not within the intended scope of the statute. The Treasury, as the Regulations reveal, is begrudgingly giving up the exceptions that are not within the intent of section 305. The fact that section 305 is directly related to so many other sections in the Code is also behind the reluctance of the Service. This is especially true in regards to the recent governmental and congressional attack on the conglomerates. Because section 305 and the reorganization sections are so intimately 
associated, an effective control of the conglomerates is only a step away.

There are many questions to be answered, but the necessary exceptions can be carved out of section 305 through Regulations and cases. The Treasury and the courts will be making these exceptions based upon the Code as a whole and the more general intent of Congress not to give unbridled authority to the Treasury.

Regardless of how it might otherwise be described, whether by the Treasury or a court, the theory of realization will be the most widely used determining rod. The present status and treatment of stock dividends has thus been returned to the pure Eisner v. Macomber distribution, with a stock dividend generally being non-taxable only when it resembles the purist form of a stock split. 